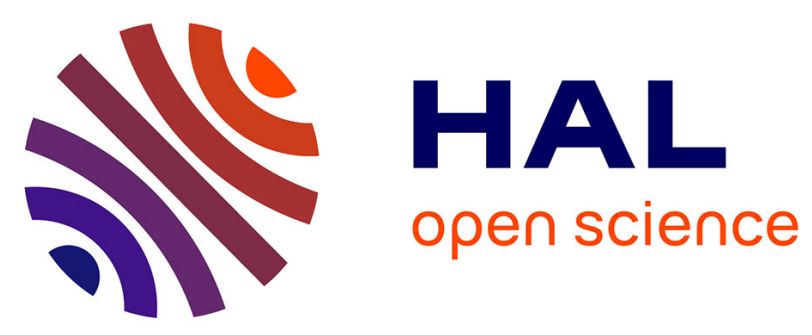

\title{
Degradation of $\beta$-carotene during fruit and vegetable processing or storage: reaction mechanisms and kinetic aspects: a review
}

Caroline Pénicaud, Nawel Achir, Claudie Dhuique-Mayer, Manuel Dornier, Philippe Bohuon

\section{To cite this version:}

Caroline Pénicaud, Nawel Achir, Claudie Dhuique-Mayer, Manuel Dornier, Philippe Bohuon. Degradation of $\beta$-carotene during fruit and vegetable processing or storage: reaction mechanisms and kinetic aspects: a review. Fruits, 2011, 66 (6), pp.417-440. 10.1051/fruits/2011058 . hal-01506490

\author{
HAL Id: hal-01506490 \\ https://hal.science/hal-01506490
}

Submitted on 14 Jun 2018

HAL is a multi-disciplinary open access archive for the deposit and dissemination of scientific research documents, whether they are published or not. The documents may come from teaching and research institutions in France or abroad, or from public or private research centers.
L'archive ouverte pluridisciplinaire HAL, est destinée au dépôt et à la diffusion de documents scientifiques de niveau recherche, publiés ou non, émanant des établissements d'enseignement et de recherche français ou étrangers, des laboratoires publics ou privés. 


\title{
Degradation of $\beta$-carotene during fruit and vegetable processing or storage: reaction mechanisms and kinetic aspects: a review
}

\author{
Caroline Pénicaud, Nawel ACHIR*, Claudie Dhuique-MaYer, Manuel Dornier, Philippe Bohuon
}

Cirad-Persyst, UMR 95 Qualisud, TA B-95 / 16, 73 rue Jean-François Breton, F-34398 Montpellier, France nawel.achir@cirad.fr

${ }^{*}$ Correspondence and reprints

Received 30 June 2010 Accepted 3 December 2010

Fruits, 2011, vol. 66, p. 417-440 (C) 2011 Cirad/EDP Sciences All rights reserved DOI: $10.1051 /$ fruits/2011058 www.fruits-journal.org

RESUMEN ESPAÑOL, p. 440
Degradation of $\beta$-carotene during fruit and vegetable processing or storage: reaction mechanisms and kinetic aspects: a review.

Abstract - Introduction. Food processing significantly lowers the quality of fruits and vegetables, which is a major concern for the food industry. Micronutrients are particularly affected, and among them $\beta$-carotene, which exhibits very interesting sensory, nutritional and biological properties. The literature concerning $\beta$-carotene degradation is extensive, but the conclusions are very different as a function of the biological, chemical and food transformation points of view. This paper proposes a synthesis of complementary approaches in the study of $\beta$-carotene during food transformation and storage. Degradation reactions. Degradation compounds are numerous, including isomers, epoxides, apocarotenones, apocarotenals and short-chain cleavage products, among them some flavour compounds. A detailed reaction scheme of isomerisation and autoxidation of $\beta$-carotene could be deduced from the literature data. The main pathways are well documented, but the global reaction scheme is still incomplete. Furthermore, most of the mechanistic studies are carried out in model systems, thus data may misrepresent $\beta$-carotene behaviour in real food products. Kinetics during processing and storage. The determination of degradation kinetics permits the identification of the fastest reactions, i.e., generally those with the greatest impact, and also the quantification of the effect of the factors which can lower $\beta$-carotene content. Temperature, occurrence of oxygen, food composition and food structure are shown to affect the $\beta$-carotene loss rate significantly. However, the methodologies used to obtain the kinetic parameters are of major importance, and finally, most of the results found in the literature are specific to a study and difficult to generalise. Discussion and conclusion. Mechanistic and kinetic approaches each provide interesting data to improve understanding and monitoring of $\beta$-carotene. The combination of all this data, together with thermodynamic and analytical considerations, permits the building of observable reaction schemes which can further be transcribed through mathematical models. By this multidisciplinary approach, scarcely used for the time being, knowledge could be capitalised and useful tools could be developed to improve $\beta$-carotene retention during food processing and storage.

France / fruits / vegetables / storage / processing / carotenoids / isomerisation / oxidation / degradation / chemical reactions

\section{La dégradation du $\beta$-carotène au cours de la transformation ou du stockage des} fruits et des légumes: mécanismes réactionnels et aspects cinétiques: une revue.

Résumé - Introduction. La diminution significative de la qualité des fruits et légumes au cours de leur transformation est une préoccupation majeure de l'industrie alimentaire. Les micronutriments sont particulièrement affectés, et, parmi eux, le $\beta$-carotène qui présente d'intéressantes propriétés sensorielles, nutritionnelles et biologiques. La littérature traitant de la dégradation du $\beta$-carotène est très dense, mais la nature des conclusions diffère en fonction de l'approche biologique, chimique ou technologique du problème. Notre article propose une synthèse de points de vue complémentaires dans l'étude du $\beta$-carotène pendant la transformation et le stockage des aliments. Réactions de dégradation. Les principaux composés de dégradation du $\beta$-carotène identifiés sont les isomères, les époxides, les apocaroténones, les apocaroténals et les produits de clivage à courte chaîne, dont des composés d'arômes. Un schéma réactionnel détaillé des réactions d'isomérisation et d'auto-oxydation du $\beta$-carotène a pu être déduit des données de la littérature. Les voies principales sont bien documentées, mais le schéma réactionnel global reste incomplet. De plus, la plupart des études mécanistiques sont menées en système modèle, donc les données peuvent mal représenter le comportement du $\beta$-carotène dans des aliments réels. Cinétiques pendant les procédés et le stockage. La détermination des cinétiques de dégradation permet l'identification des réactions les plus rapides, c'est-à-dire généralement celles qui ont les impacts les plus forts, ainsi que la quantification de l'effet des facteurs qui peuvent diminuer la teneur en $\beta$-carotène. La température, la présence d'oxygène, la composition et la structure affectent significativement la vitesse de perte en $\beta$-carotène. Cependant, les méthodologies employées pour obtenir les paramètres cinétiques sont d'importance majeure et, finalement, la plupart des résultats trouvés dans la littérature sont spécifiques d'une étude et difficilement généralisables. Discussion and conclusion. Les approches mécanistiques et cinétiques fournissent chacune des données intéressantes pour améliorer la compréhension et le suivi du $\beta$-carotène. La combinaison de l'ensemble de ces données, avec aussi des considérations thermodynamiques et analytiques, permet de construire des schémas réactionnels observables qui peuvent ensuite être transcrits en modèles mathématiques. Par cette approche multidisciplinaire, rarement utilisée actuellement, les connaissances pourraient être capitalisées et des outils utiles pourraient être développés pour améliorer la rétention du $\beta$-carotène pendant les transformations alimentaires et le stockage.

France / fruits / légume / stockage / traitement / caroténoïde / isomérisation / oxydation / dégradation / réaction chimique 


\section{Introduction}

Carotenoids are among the most important pigments in fruits [1]. These tetraterpenes synthesised by plants are secondary metabolites essential for photosynthesis and to prevent photo-oxidation induced by light intensities. These functions are a consequence of the light-absorbing properties of their polyene chromophore. Carotenoids consist of two classes of molecules: (i) the carotenes, which are strictly hydrocarbons, and (ii) the xanthophylls, or oxycarotenoids, which contain one or more oxygen functions [2]. $\beta$-carotene, which belongs to the first class, is the most widespread in foods. $\beta$-carotene is encountered at high concentrations in many fruits and vegetables such as carrot, spinach, sweet potatoes, plantain (Musa spp.), apricot, orange, etc. [3]. One of the richest fruits is palm fruit, with a concentration of $200 \mathrm{mg} \beta$-carotene $\cdot \mathrm{kg}^{-1}$ (table I).

$\beta$-carotene's chemical formula is $\mathrm{C}_{40} \mathrm{H}_{56}$. It is composed of eight isoprenic units with specific end groups or two $\beta$-ionone rings (figure 1). $\beta$-carotene is lipophilic, insoluble in water and soluble in organic solvents such as petroleum ether, hexane, etc. Its physical, chemical and biological properties are mainly derived from its large sequence of conjugated double bonds. Firstly, the sin- gle and double bond alternation causes the delocalisation of the $\pi$ electrons and makes possible the absorption of light within the range of the visible spectrum. $\beta$-carotene absorbs blue and purple light with a maxima at $450 \mathrm{~nm}$ and therefore has a strong redorange colour [4]. These chromophore properties were initially used for its isolation, characterisation and quantification on the laboratory or the industrial scale [5]. $\beta$-carotene is also currently used as a food additive belonging to the colouring family, with the European denomination E 160; it is increasingly employed because of the tendency in the food industry to replace synthetic colouring agents with natural ones. This additive can be produced by palm oil concentration or extraction of paprika oleoresin $[6,7]$. $\beta$-carotene is thus an important component of the organoleptic quality of food, not only because of its colour, but also due to its precursor role of aroma compounds such as norisoprene and monoterpene during fruit ripening [1].

The role of carotenoids in human nutrition is not based upon the light-absorbing properties of these molecules but on the nutritional activity as provitamin A [8]. Along with $\alpha$-carotene and $\beta$-cryptoxanthin, $\beta$-carotene is a vitamin A precursor, because of its perfect structure of vitamin A dimers. Therefore, it is stoichiometrically

Table I.

Composition of some $\beta$-carotene-rich fruits and vegetables.

\begin{tabular}{|c|c|c|c|}
\hline Fruit & $\begin{array}{l}\beta \text {-carotene content } \\
\left(\mathrm{mg} \cdot \mathrm{kg}^{-1}\right)\end{array}$ & $\begin{array}{c}\beta \text {-carotene of total carotenoids } \\
(\%)\end{array}$ & Reference \\
\hline Apricot & 11 & 84 & USDA $^{a}$ \\
\hline Carrot & $65-83$ & $67-70$ & USDA $^{\mathrm{a}}[92]$ \\
\hline Lettuce & $10-14$ & 47 & [90] \\
\hline Orange & $0.1-1.4$ & $1-9$ & {$[95,96]$} \\
\hline Orange sweet potato & $85-93$ & $90-100$ & $\mathrm{USDA}^{\mathrm{a}}[17,90]$ \\
\hline Palm fruit & 200 & 54 & {$[76,93]$} \\
\hline Plantain & $4-10$ & 44 & [95] \\
\hline Pumpkin & $12-31$ & 55 & $\operatorname{USDA}^{\mathrm{a}}[5,91]$ \\
\hline Spinach & $9-19$ & 30 & {$[90]$} \\
\hline
\end{tabular}




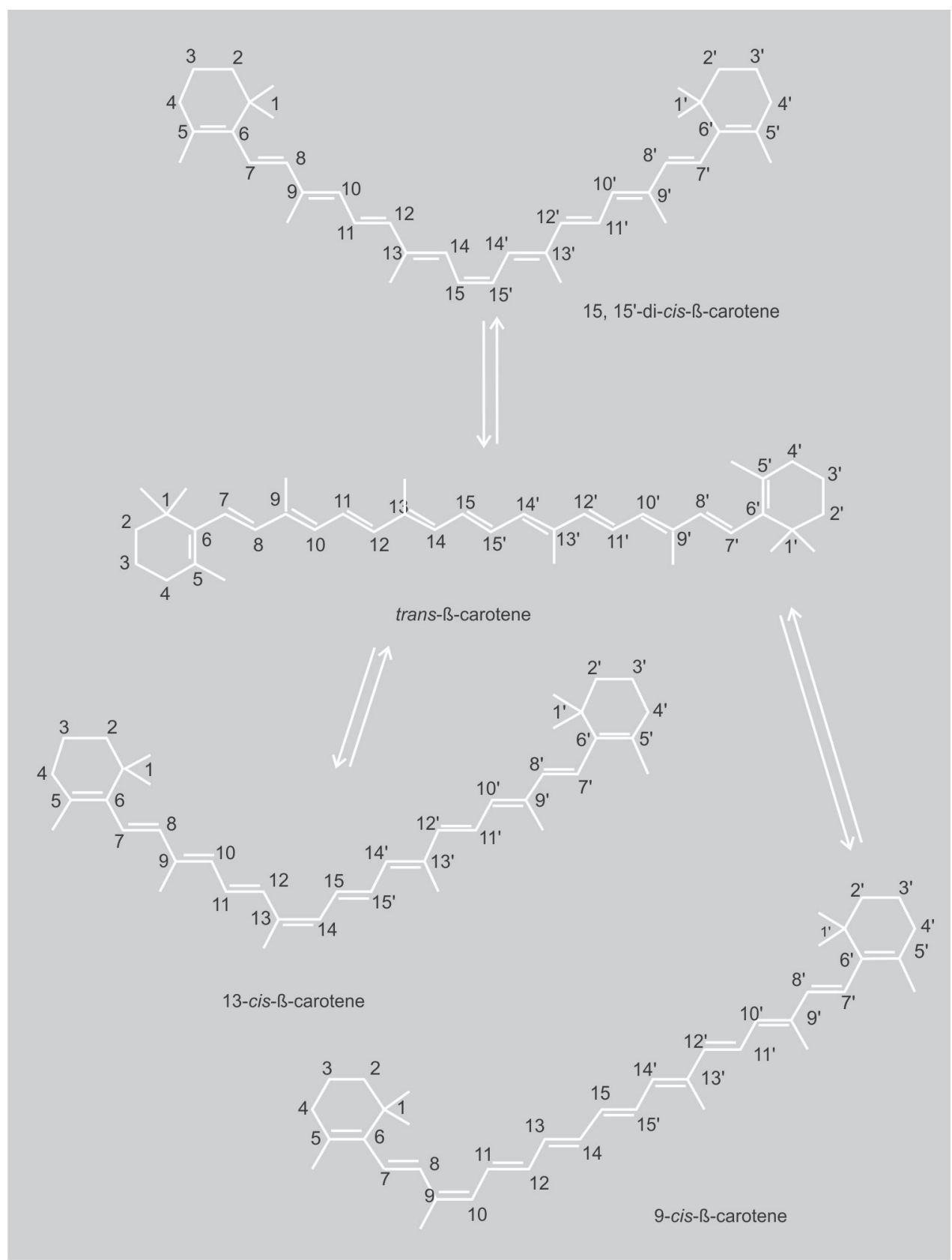

Figure 1.

Trans- $\beta$-carotene and its main isomers: 15 -cis-, 13-cis- and 9 -cis- $\beta$-carotene.

equivalent to two molecules of retinol [4, 9]. The enzyme, $\beta$-carotene 15,15 ' monooxygenase, present in the human intestinal cells and liver, acts on the 15,15' bond, thus forming two equivalent-retinol molecules from one molecule of $\beta$-carotene by central cleavage [10]. $\beta$-carotene is the main important source of vitamin A, particularly in developing countries. This molecule also has the ability to be an efficient antioxidant because of its highly delocalised electrons which can stabilise by resonance reactive intermediates such as carbocations or radicals. $\beta$-carotene can thus protect cellular tissues by quenching singlet oxygen and scavenging active free radicals that are involved in potentially lethal processes, such as lipid peroxidation [2, 11-13]. 


\section{Pénicaud et al.}

Because of this antioxidant activity, $\beta$-carotene is often used in food complements or for pharmaceutical applications. On the food scale, because of its lipophilic properties, $\beta$-carotene can be used in oils where it can protect unsaturated lipids against peroxidation [14].

$\beta$-carotene, by its structure, exhibits very interesting sensory, nutritional and biological properties. However, its significant number of double bonds makes it very sensitive to degradation and particularly to oxidation. Indeed, while $\beta$-carotene concentration increases during fruit ripening [15], its concentration stagnates or decreases during post-harvest storage at rates varying as a function of the temperature [16]. However, the main critical step for $\beta$-carotene loss remains during fruit processing, i.e., juice or puree production. Indeed, the loss of tissue integrity, contact with oxygen and light, and the elevation of temperature during thermal treatment dramatically increase the rates of degradation reactions [4, 17].

The main degradation products identified after food processing are isomers, oxidation and cleavage products $[18,19]$. These compounds may lower the sensory and nutritional properties of the resulting food products. For instance, it was demonstrated that the cis-isomers of $\beta$-carotene have lower antioxidant properties than trans- $\beta$ carotene [3] and generate about two-fold less vitamin A [20]. In addition, some studies reported the increase in oxidative stress caused by end products of carotene $\beta$-oxidation [21]. These results show how a food process can be damaging and the important issue is to control conditions such as temperature, light or oxygenation in order to improve $\beta$-carotene retention in processed food.

The aim of our paper is to present a literature synthesis about the theory of $\beta$-carotene degradation and its application during food processing and storage. The literature concerning $\beta$-carotene degradation is extensive, and the approaches are very different as a function of the biological, chemical and food transformation points of view. Biological and chemical studies focus on the degradation mechanisms, while food-processing work is more devoted to degradation kinetics in order to optimise process design. Although these approaches are complementary to improve $\beta$-carotene retention during food transformations, data are actually dispersed and they need to be gathered. The first part of this review will deal with the current knowledge about the chemistry of the $\beta$-carotene degradation mechanisms. The second part will be dedicated to the study of reaction kinetics, and especially the different approaches to monitoring kinetics in food processes and the effects of storage or process conditions. Finally, the conclusion will evidence the importance of both approaches to improve the comprehension and the prediction of $\beta$-carotene degradation to further prevent it during food processing.

\section{Degradation reactions}

$\beta$-carotene is a very reactive compound due to its highly unsaturated structure, which renders it electronically rich by delocalisation of $\pi$-electrons. Consequently, it is also prone to degradation and more precisely to isomerisation, especially at high temperature, and oxidation, due to the occurrence of oxygen in food [4]. Molecular oxygen is a diradical, so it cannot react directly with food components, except if the food compounds become radical compounds or if active forms of oxygen are produced. Mordi showed that the products of $\beta$-carotene oxidation by molecular oxygen are similar to the products obtained in the singlet oxygen oxidation (one active oxygen specie) [22]. The involvement of radical species would explain the similarity in product formation in the two reactions. Current thinking is that the whole process involves first isomerisation of the all-trans to the cis-isomer, followed by the formation of a diradical, or they may both occur simultaneously and reversibly (figure 2). The involvement of cis/trans isomerisation in $\beta$-carotene oxidation was more recently noted by Mohamed et al., who showed that the lowest energy configuration may occur from oxidative attack of 9-cis- $\beta$-carotene and then 13cis- $\beta$-carotene, before trans- $\beta$-carotene [9]. These findings show that isomerisation and 


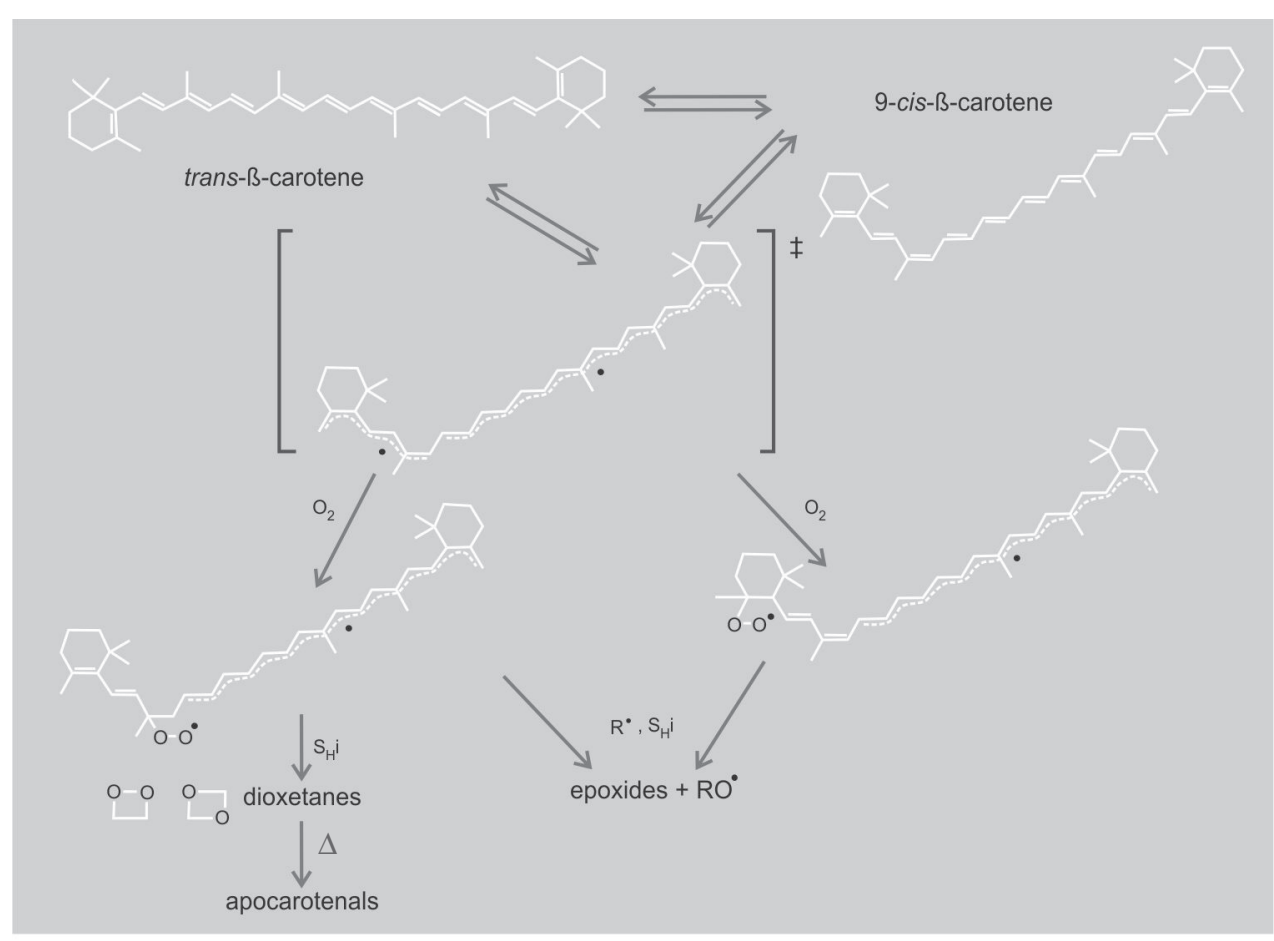

oxidation are closely linked and must generally be studied together.

\subsection{Isomerisation}

Trans- $\beta$-carotene is predominant in nature [23]. However, significant amounts of the cis forms can be found in processed foods. Cis isomers present one or two configuration changes at the level of one or many double bonds (figure 1). These molecules have the same molecular weight as trans- $\beta$-carotene. Separation by HPLC was, however, made possible by the recent use of the stationary phase (C30) which provides a good separation of cis isomers [6, 24]. The cis isomers are identified on the basis of their spectral properties. Indeed, in comparison with the trans- $\beta$-carotene spectrum, their maximal absorption wavelength is decreased and they have an absorption band, called the "cis" peak, at a characteristic position about $142 \mathrm{~nm}$ below the longest-wavelength absorption maximum [19, 25]. Cis isomerisation mainly takes place because of heat. As a consequence, many studies have reported the decrease in trans- $\beta$-carotene and the concomitant increase in cis isomers in vegetables rich in $\beta$-carotene because of thermal processes such as blanching, pasteurisation, sterilisation and air drying [18, 26]. Light can also favour $\beta$-carotene isomerisation but to a smaller extent in comparison with the temperature effect. For instance, in the experiments of Chen and Huang, isomerisation of $\beta$-carotene in hexane reached the same level in $40 \mathrm{~min}$ at $70{ }^{\circ} \mathrm{C}$ in the dark and in 12 hours at $-5^{\circ} \mathrm{C}$ under 2000 lux [27]. Theoretically, depending on the number of double bonds, a multitude of mono- and poly-cis isomers can be formed from a given carotenoid. However, in the case of $\beta$-carotene, the major cis forms of $\beta$-carotene found after thermal processing were $15-15$ '-di-cis- $\beta$-carotene, 13 -cis- $\beta$ carotene and 9 -cis- $\beta$-carotene, but with a more significant amount of 13 -cis- $\beta$-carotene [18, 26, 28-31]. A molecular modelling study of Mohamed et al. showed that trans$\beta$-carotene configuration was the lowest energy structure but, among cis isomers, the lowest energy configurations were 9-cisand 13 -cis- $\beta$-carotene [9]. This more significant stability may explain why both cis isomers are found in high amounts in processed food. Based on the apparition
Figure 2.

First steps of $\beta$-carotene oxidation including firstly isomerisation, secondly production of radical species, and then apparition of cleavage products [22]. 


\section{Pénicaud et al.}

order of compounds, which can give an idea of the succession of intermediary products, Marx et al. also stated that, among the cis isomers, the 13 - and 15-15'-di-cis- $\beta$-carotene were predominant at low temperature, while 9-cis- $\beta$-carotene was formed under more severe conditions [26]. The amount of the different isomers formed is thus very dependent on the thermal conditions but also on the solvent and the state of $\beta$-carotene (see section 3.).

\subsection{Oxidation}

In comparison with isomerisation reactions, the resulting products of oxidative reactions are much more numerous and different in terms of molecular weight, chemical functions, etc. $\beta$-carotene can be oxidised according to three pathways. Indeed, oxidation of $\beta$-carotene can be either autoactivated (autoxidation), or induced by light (photo-oxidation) or catalysed by enzymes (enzymatic oxidation). Enzymatic oxidation can occur in fruits essentially because of lipoxigenases. However, bleaching can inactivate these enzymes. For instance, Dutta et al. observed higher $\beta$-carotene retention in bleached pumpkin than in fresh pumpkin puree due to enzyme inactivation by heat [5]. Also, during the storage of dehydrated carrot slices, Koca et al. found lower decoloration rates for blanched than unblanched products [32] (table II). Regarding photo-oxidation, Chen and Huang compared the effects of temperature and light on $\beta$-carotene degradation and found a kinetic constant increased by a factor 24 during oven heating at $150{ }^{\circ} \mathrm{C}$ compared with illumination of 2000 lux at $-5^{\circ} \mathrm{C}$, proving that the effect of light was negligible compared with that of temperature [27]. Also, Rodriguez and Rodriguez-Amaya did not find a major impact of light exposure on $\beta$-carotene degradation in the time scale chosen (21 days) [19]. In addition, photo-oxidation can be easily avoided during a process by preventing light around the product, and also by dark packaging during storage. Finally, autoxidation is the most difficult phenomenon to prevent during food processing and storage and some authors have attempted to improve knowledge about the reaction scheme.

As suggested in the detailed reaction scheme deduced from the literature (figure 3), it is supposed that isomerisation could be the first step of oxidation, leading to a diradical of $\beta$-carotene which can easily be attacked by oxygen on either side of the cis bond. This radical attack followed by homolytic internal substitution gives the epoxides, which appear as initial products. The stable final products, the apocarotenones and apocarotenals, could be formed from the epoxides.

\subsubsection{The initial oxidation products: the epoxides}

The oxygen can attack the $\beta$-carotene molecule either on the $\beta$-ring or on the chain. The homolytic hydrogen extraction could be easier at the level of the $\beta$-ring. Indeed, the molecular modelling study of Mohamed et al. showed that this position was preferably attacked by oxygen species because of its long lifetime and low energy [9]. This computational study also showed that the oxygen attack could be preferentially done on the trans-isomer, the more stable form of $\beta$-carotene. To identify the resulting products of epoxidation, Rodriguez and Rodriguez-Amaya carried out a controlled oxidation of $\beta$-carotene in a model system with chloroperbenzoic acid in ambient conditions, in the presence and absence of light [19]. They identified $\beta$-carotene-5,6-epoxide, $\beta$-carotene-5,8-epoxide, $\beta$-carotene5,6,5',6'-diepoxide, $\beta$-carotene-5,6,5',8'-diepoxide and $\beta$-carotene- $5,8,5$ ', 8 '-diepoxide. The 5,8-epoxide groups are also known as furanoid groups. The supposed relationship between these different epoxides and diepoxides is presented in figure 4 . At the level of real food, analysis of carotenoid degradation products during thermal processing of citrus juice $\left(75^{\circ} \mathrm{C}-100^{\circ} \mathrm{C}\right)$ confirmed that the isomerisation of the epoxide function in position 5,6 into a furanoxide function in position 5,8 was a common reaction for several xanthophylls [33]. Organic acids liberated during the processing of fruit juices are strong enough to promote rearrangements of 5,6-epoxide groups into furanoid groups. To the contrary, no evidence was found on 


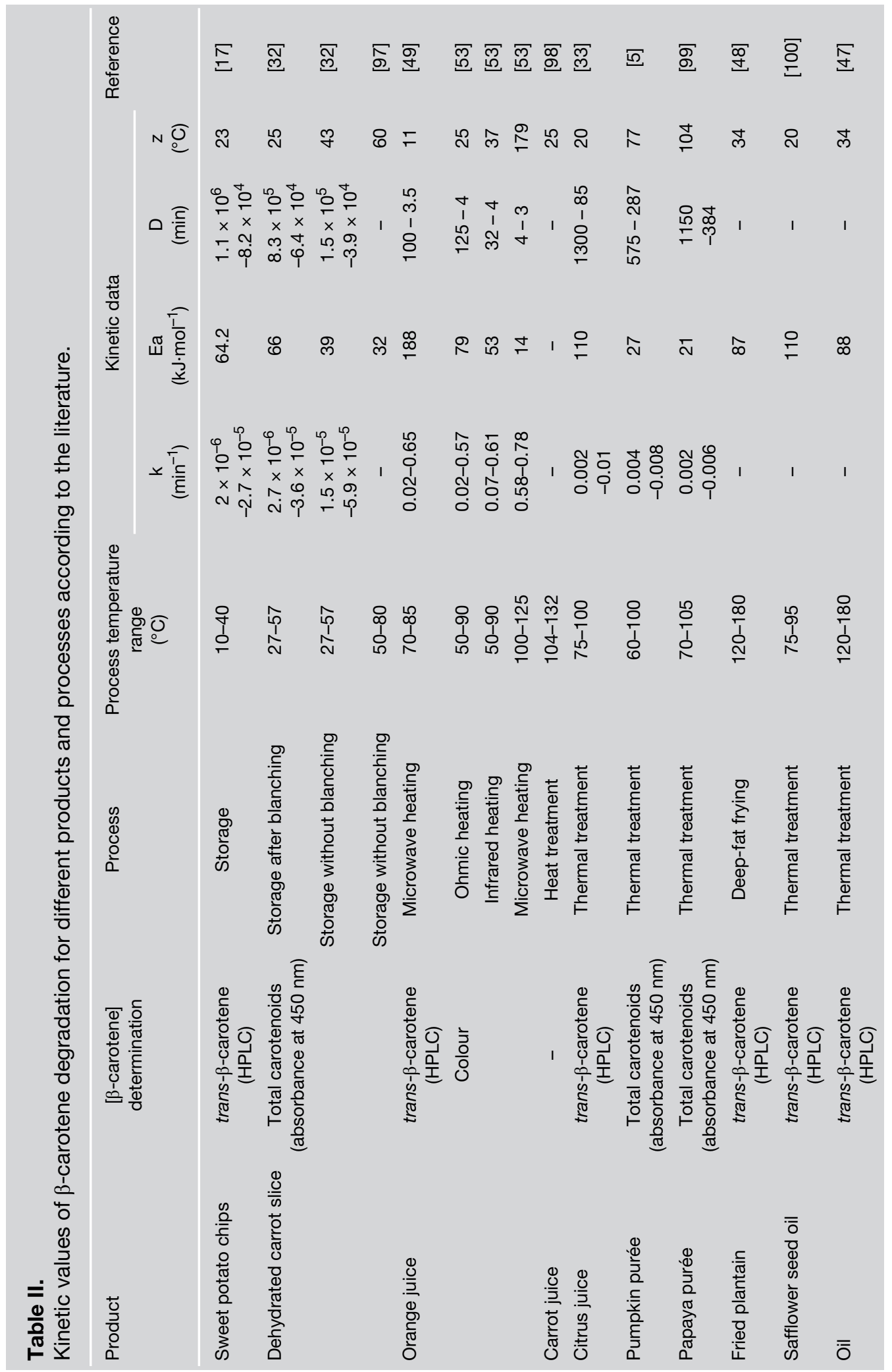




\section{Pénicaud et al.}

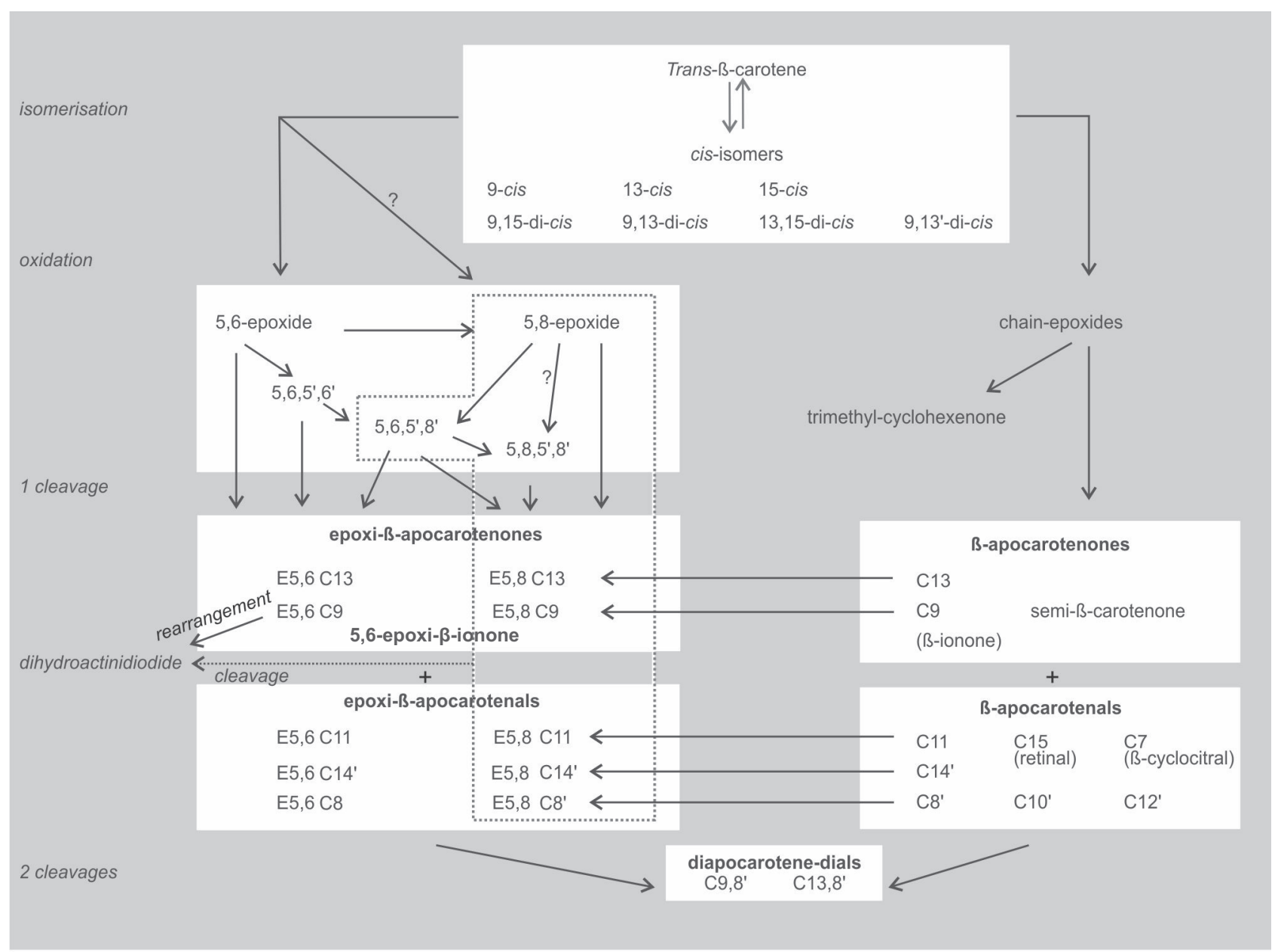

Figure 3.

General overview of the degradation scheme of $\beta$-carotene. the ability of $\beta$-carotene to form furanoid directly without going through the 5,6epoxide intermediate.

If the attack of the oxygen molecule is done on the polyene chain of $\beta$-carotene, inchain epoxides are formed. In this case, oxygen attack is preferentially done on cis isomers (figure 2), due to the higher availability of the $\pi$-electrons in these cis configurations. The in-chain epoxides have been identified as precursors of cleavage products [34], namely the apocarotenones and the apocarotenals.

\subsubsection{Apocarotenones and apocarotenals}

Cleavage can occur (i) from a chain epoxide which can be formed directly from a cis isomer, or (ii) from a second oxygen attack on a 5,6-epoxide or furanoid compound, in which case the cleavage products are named epoxy- $\beta$-apocarotenals and epoxy- $\beta$-apocarotenones (figure 3). The complete range of $\beta$-apocarotenals and $\beta$-apocarotenones as well as diapocarotene-dials that can possibly be formed from trans- $\beta$-carotene have been detected during an experiment of mild oxidative cleavage by dioxygen induced by a ruthenium tetramesitylporphyrin catalyst [34]. All these cleavage products are presented in figure 4. In the experiments of Rodriguez and Rodriguez-Amaya, epoxidation with $m$ chloroperbenzoic acid and oxidative cleavage with potassium permanganate led to products identified as $\beta$-apo- 8 '-carotenal, $\beta$-apo-10'-carotenal, $\beta$-apo-12'-carotenal, $\beta$-apo14 '-carotenal and $\beta$-apo-15-carotenal, along with semi- $\beta$-carotenone and monohydroxy$\beta$-carotene-5,8-epoxide [19]. These products 

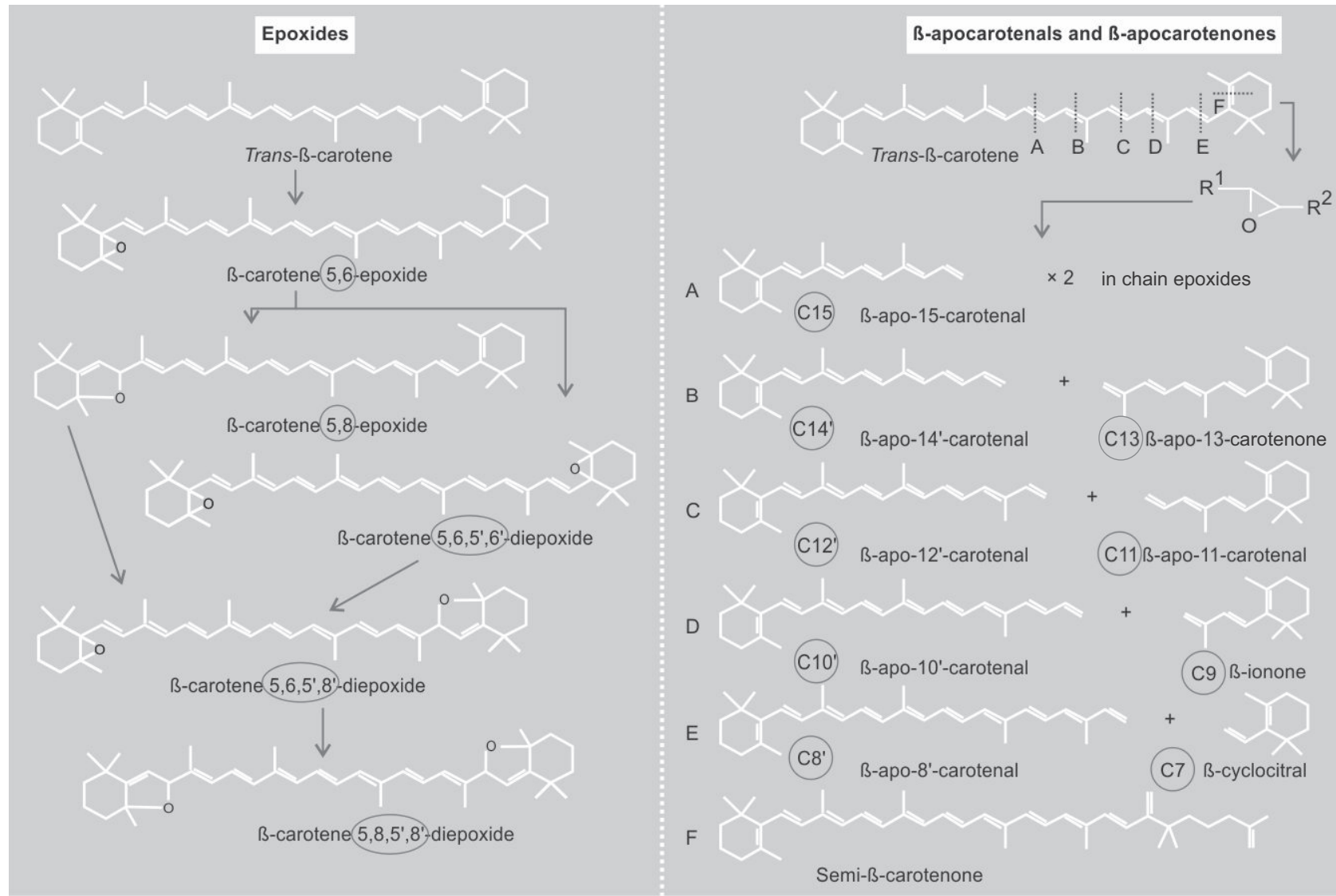

were detected in model systems and some of these products were also found in mango juice, acerola juice and dried apricot. Increased cis isomerisation was also observed and cis isomers of the oxidation products were detected.

\subsubsection{Short-chain cleavage products}

Some authors concentrated their work on short-chain cleavage products (maximum of 9 atoms of carbon) and mostly on norisoprenoids, known as flavour compounds. These compounds are issued from $\beta$-carotene, apocarotenones or apocarotenal cleavage. Most of the works aimed at characterising the products formed by degradation of $\beta$-carotene. For instance, in oak wood, $\beta$-ionone, 5,6-epoxy- $\beta$-ionone and dihydroactinidiolide were identified [35]. In biological tissues, Sommerburg et al. identified 5,6-epoxy- $\beta$-ionone, ionene, $\beta$-cyclocitral, $\beta$-ionone, dihydroactinidiolide and 4-oxo- $\beta$-ionone as cleavage products formed after degradation of $\beta$-carotene mediated by hypochlorous acid [36]. Non-enzymatic cleavage of carotenoids was supposed to be carried out primarily by oxidants liberated by polymorphonuclear leukocytes.

From a mechanistic point of view, only the dihydroactinidiolide was submitted to investigations on its formation pathways, and at least two reaction pathways could be evidenced (figure 3). Bosser and Belin described a system able to generate free radicals to cleave $\beta$-carotene, giving rise to $\beta$-ionone, 5,6-epoxy- $\beta$-ionone and dihydroactinidiolide [37]. Under these conditions, in another study and at $37^{\circ} \mathrm{C}$, two main reaction pathways could be put forward [38]: one would involve a free radical oxidising mechanism, leading to $\beta$-ionone, then to 5,6epoxy- $\beta$-ionone, and then to dihydroactinidiolide. This way links the 5,6-epoxy- $\beta$ ionone to its precursor $\beta$-ionone. The

\section{Figure 4.}

Detailed formation of epoxides [19] and $\beta$-apocarotenals and $\beta$-apocarotenones [34] from the degradation of $\beta$-carotene. 


\section{Pénicaud et al.}

second would involve a thermal process, leading from the 5,6-epoxy- $\beta$-ionone to the dihydroactinidiolide exclusively, at $37^{\circ} \mathrm{C}$. Free radicals and variation in $\mathrm{pH}$ value did not modify in a significant manner the yield or the kinetics of this reaction. From a more theoretical point of view, according to predictions from calculations of minimal free energies of oxidation [39], for $\beta$-carotene, the favoured cleavage would be $\beta$-cyclocitral (C7) and $\beta$-apo-8'-carotenal (C8') whereas for the 9-cis-isomer, the favoured cleavage bond would be the cis bond (9-10), giving rise to $\beta$-ionone (C9) and $\beta$-apo-10'-carotenal (C10'). Experimentally, Wache et al. showed that higher ratios of 9-cis- $\beta$-carotene increased the formation of dihydroactinidiolide [39]. However, the authors were not sure whether the 9-10 cleavage site was favoured, as proposed by the prediction, or if the 9-cis-isomer was first transformed into its epoxide and then cleaved at the 8-9 level. All these studies support the idea that at least two ways can be followed to produce dihydroactinidiolide, as shown in figure 3.

\subsubsection{Unclear reaction pathways}

Whilst this general degradation scheme (figure 3) is supported by the findings of Mordi et al. [40], some other compounds were also found. Epoxides, dihydrofurans and carbonyl compounds, but also carbon dioxide, oligomeric material, traces of alcohols, and probably carboxylic acids were formed. The main products in the early stage of the oxidation were shown to be 5,6-epoxy- $\beta$-carotene, 15,15 '-epoxy- $\beta$-carotene, diepoxides, and a series of $\beta$-apo-carotenals and $\beta$-carotenones. As the oxidation proceeded, uncharacterised oligomeric material and the carbonyl compounds became more significant while the epoxides degraded. In the final phase of the oxidation, the longerchain $\beta$-apo-carotenals were themselves oxidised to shorter-chain carbonyl compounds, particularly $\beta$-apo-13-carotenone, $\beta$-ionone, 5,6 -epoxy- $\beta$-ionone, dihydroactinidiolide and probably carboxylic acids. The oxidation of $\beta$-apo- 8 '-carotenal and retinal under similar conditions was studied briefly, and the main products from the former compound were characterised.
Some compounds identified in the literature are not in figure 3 because their mode of apparition/degradation remains unclear: dioxetanes [22], monohydroxy- $\beta$-carotene5,8-epoxide [19], ionene and 4-oxo- $\beta$ ionone [36], dihydrofurans, carbon dioxide, uncharacterised oligomeric material, traces of alcohols and supposed carboxylic acid [40], and polymers of $\beta$-carotene [41] observed together with degradation when $\beta$-carotene was heated and exposed to air.

As all the compounds found as degradation products could not be integrated, figure 3 is necessarily a simplification of the real reaction scheme. Moreover, this scheme does not take into account the radical nature of the reactions. Indeed, the initiation, the formation of the epoxides, the $\beta$-apo-carotenals and $\beta$-carotenones, the successive chain shortening of the aldehydes to the ketones, and the formation of dihydroactinidiolide have been explained in terms of free radical peroxidation chemistry [40]. Epoxide formation has been shown to be accompanied by the release of an alcoxyl radical that may continue the chain oxidation $[22,42,43]$. Also, more $\beta$-carotene peroxyl radicals are formed at higher concentrations of $\beta$-carotene. Thus, both epoxide formation and $\beta$-carotene peroxyl radical formation enhance the chain oxidation.

The studies which allowed building this reaction scheme also have their own limits. In most cases, experiments were carried out in model systems. This is a good way to investigate a research area from a theoretical point of view, but does not necessarily fit reality in food, as illustrated by the work of Rodriguez and Rodriguez-Amaya, who did not find in mango juice, acerola juice and dried apricot all the products detected in the model systems [19]. The lack of studies in real food products renders impossible the establishment of clear correlations between food nature and composition and the preferred reaction pathways. Moreover, mass balances are never complete in studies about carotenoids, especially in real foods, due to the very high number of compounds involved in the overall reaction scheme. It is obviously very hard to fully quantify all compounds during one experiment, not only due to the time needed for the analysis 
itself, but also because some of these compounds can stay in the product; so an extraction stage would be necessary before analysis, or can go in the gas phase, where loss can easily occur between their production and their quantification. Even though, nowadays, the use of HPLC, mass spectrometry and Electron Spin Resonance (ESR) makes the identification and the quantification of a very significant quantity of degradation products possible [44]. However, analytical techniques still have their current limits, especially in quantification limit, which may prevent full quantification of all compounds.

Considering all these difficulties to establish a complete degradation scheme of $\beta$-carotene, and above all the influence of the food's nature and composition on the reaction pathways, the examination of degradation kinetics appears to be completely necessary in order to i) identify the most important reactions in terms of rate, and ii) quantify the factors which can affect the kinetic values.

\section{Kinetics of $\beta$-carotene degradation during fruit processing or storage}

The level of $\beta$-carotene in processed fruits and vegetables is essential in nutritional and commercial terms for the industry since fruits and vegetables are the principal sources of $\beta$-carotene and vitamin A precursor. The guarantee of a maximal preservation of $\beta$-carotene is thus an interesting commercial argument. But labelling a fruit juice with a guaranteed content of $\beta$-carotene after processing and during storage requires good knowledge of $\beta$-carotene degradation kinetics for the determination of the optimal shelf life. Indeed, significant losses occur during processing and storage, and many factors such as time, temperature or occurrence of oxygen can significantly affect $\beta$-carotene retention. For instance, in orange sweet potatoes Wu et al. found from $8 \%$ up to $66 \%$ of $\beta$-carotene loss by using different food cooking processes [45]. The quantified knowledge of the parameters which impact $\beta$-carotene degradation is therefore important for the choice and the design of a process or the selection of the best storage conditions to provide products with higher nutritional potential.

\subsection{Kinetic model for $\beta$-carotene loss}

Most of the studies in real food report a oneorder reaction with respect to the concentration of $\beta$-carotene:

$$
\left[\ln \left(\frac{[\beta-\text { carotene }]_{t}}{[\beta-\text { carotene }]_{t=0}}\right)=-k \cdot t\right]
$$

where $[\beta-$ carotene $]$ is the content of $\beta$-carotene, $k$ the reaction rate constant, and $t$ the time given in s (SI units), or more frequently in min.

Some authors also use the representation usually used for microorganism inactivation kinetics during thermal processes:

$$
\left[\log \left(\frac{\left[\beta-\text { carotene }_{t}\right.}{[\beta-\text { carotene }]_{t=0}}\right)=-\frac{t}{D}\right]
$$

where $D$ is the decimal reduction time in min, i.e., the time required to reduce the $\beta$-carotene concentration by $90 \%, D$ is related to the reaction rate constant by $D=[\ln (10) / k]$.

The use of a one-order kinetic is realistic in many cases. From this model, the degradation rate constant or decimal reduction time can be easily calculated. However, some studies tested superior reaction orders by linearisation methods [46] or non-linear regression [47] and found a better fit of experimental data with orders superior than one for trans- $\beta$-carotene degradation in non-polar solvents. This fact may be explained by the competition with isomerisation reactions particularly important in these types of solvents [27].

The concentration of $\beta$-carotene can be obtained by HPLC [17, 33, 48, 49]. However, in kinetic studies, the spectrophotometric method after extraction is more usually employed because of its lower time and money cost [5, 32, 50]. However, this method may evaluate not only trans- $\beta$-carotene 


\section{Pénicaud et al.}

concentration but also its cis-isomers and oxidised products which also absorb at $450 \mathrm{~nm}$ and with different response coefficients than that of trans- $\beta$-carotene [4]. Lastly, some kinetic studies also propose a kinetic evaluation of $\beta$-carotene loss from the monitoring of a physical property supposed to be correlated with $\beta$-carotene content, such as colour. This measurement of $\beta$-carotene content is convenient since it avoids a significant experimental effort. However, the resulting kinetic data are quite meaningless from a chemical point of view since colour may come from other pigments and, during thermal processes, other reactions such as Maillard reactions are supposed to occur at the same time and also impact the product colour. Therefore, before using colour as a representative property for $\beta$-carotene loss, a correlation study must be done. Lastly, Zepka et al. provided both carotenoid concentrations and a colour parameter to evaluate $\beta$-carotene degradation in a cashew apple juice model [51]. They evaluated and correlated both responses via the same kinetic constant rates. The resulting kinetic data provided useful information for the quality control of carotenoids and the related juice nutritional value during the thermal process. For instance, it could be calculated that $\Delta E^{*}=1.9$ ( $E^{*}$ being the total colour measurement), which is visually perceived, promotes a $16 \%$ reduction of provitamin A value, whereas $\Delta E^{*}=3$ implies a more relevant $36 \%$ loss of the provitamin A value. This is obviously a result of interest for the juice industry, due to the ease of controlling colour changes in comparison with the timeconsuming chemical analysis. This type of information is also available for orange juice [52] and papaya puree [53]. Other authors suggested that in model systems, the lightness index $\left(L^{*}\right)$ seemed to be a good indicator of the decrease in $\beta$-carotene concentration, while the changes in the redness/greenness index $\left(a^{*}\right)$ coincided with the production of the volatile compound $\beta$-ionone [54].

The majority of the kinetic models used to describe $\beta$-carotene degradation are uniresponse kinetic models represented by equations (1) or (2). However, as detailed in the previous section, $\beta$-carotene is supposed to degrade in various products, mainly cis isomers, and oxidised and cleavage molecules. The real reaction scheme is much more complex, reactions are of high dynamics and are therefore hard to monitor. Indeed, the evaluation of kinetic constants is complicated by the simultaneous apparition and disappearance of intermediary products whose lifetimes can be very short, rendering tedious their detection and thus their quantification over time. To overcome these difficulties, Zepka et al. proposed a simplified multi-response model according to the reaction scheme in figure 5 to represent carotenoid degradation in a model cashew apple juice [51]. The mechanism involves parallel irreversible and reversible coupled reactions of both trans- $\beta$-cryptoxanthin and trans- $\beta$-carotene to yield, respectively, degradation compounds and monocis-isomers. Therefore, thanks to the global monitoring of the two types of products (volatile and non-volatile, respectively), they could have access to the different constant rates, discriminate the two pathways and even evaluate the temperature effect.

In many food systems, the most important extensive variable toward the reaction rate is temperature. Therefore, the temperature dependency of a reaction is important and useful information to design and determine time and temperature couples during common processes such as pasteurisation, sterilisation, canning, etc. In the literature, the temperature dependency is often given by the Arrhenius law, resulting in the calculation of an activation energy:

$$
\left[k=k_{0} \exp \left(-\frac{E_{a}}{R T}\right)\right]
$$

where $k$ is the kinetics constant rate $\left(\mathrm{s}^{-1}\right), k_{0}$ the Arrhenius pre-exponential factor $\left(\mathrm{s}^{-1}\right)$ (for a first-order kinetic), $E_{a}$ the activation energy $\left(\mathrm{J} \cdot \mathrm{mol}^{-1}\right), R$ the ideal gas constant $\left(8.314 \mathrm{~J} \cdot \mathrm{K}^{-1} \cdot \mathrm{mol}^{-1}\right)$ and $T$ the absolute temperature $(\mathrm{K})$.

The temperature dependency may also be given by the Bigelow model:

$$
\left[\log \left(\frac{D_{1}}{D_{2}}\right)=\frac{T_{2}-T_{1}}{\mathrm{z}}\right]
$$


where $D_{1}$ and $D_{2}$ are the decimal reduction time for the temperatures $T_{1}$ and $T_{2}$, respectively, and $z$ is the temperature sensitivity or thermal resistance constant in ${ }^{\circ} \mathrm{C}$.

Conversion of $E a$ and $z$ is obtained using the following relationship:

$$
\left[E a=\frac{2.03 \cdot T_{\min } \cdot T_{\max } \cdot R}{\mathrm{z}}\right]
$$

\subsection{Kinetic data for various products and conditions during storage or processing}

The literature gives kinetic data for several types of products, liquid, solid and for different process or storage conditions. Thanks to the previous equations 1 to 5 , kinetic data obtained with the $D-z$ and the $k-E a$ models were summarised for several processes and temperatures (table II).

Firstly, it can be observed that reaction rates $k$ or decimal reduction times $D$ are very different when obtained during storage or during processing. Indeed, during storage $D$ values can be easily expressed in months $[17,32]$, while they can be expressed in hours or minutes during processing $[49,53]$. These large differences are due to the significant temperature dependency of the degradation reaction to temperatures. Indeed, storage usually occurs at temperatures below $50^{\circ} \mathrm{C}$, which is not the case of thermal processing whose temperature may vary from $60{ }^{\circ} \mathrm{C}$, for pasteurisation treatments, to $100-120{ }^{\circ} \mathrm{C}$ for sterilisation, and even to $180{ }^{\circ} \mathrm{C}$ for deep-fat frying treatments. However, temperature is not the only factor influencing kinetic rate constants. Indeed, even for similar products and/or process conditions, rate constants can be very different (table II). For instance, for the same product and the same drying temperature, kinetic data may be different because of the use of a blanching step inducing enzyme destruction (see section 2.2.). More markedly, for orange and citrus juices, the $D$ values obtained for conventional heating are much higher than those obtained for microwave, ohmic or infrared treatments. This fact may be due to the much more efficient heat transfers with these non-conven- tional heating methods leading to shorter processing time but also higher $\beta$-carotene degradation. For instance, Fratianni et al. found a $\beta$-carotene degradation of about $50 \%$ after $1-\mathrm{min}$ microwave heating at $75^{\circ} \mathrm{C}$ [49], while Dhuique et al. found the same degradation after $250 \mathrm{~min}$ [33]. The $D$ values are even higher for products such as papaya or pumpkin purees, having high viscosities that limit the heating.

For each process (table II), the kinetic study of $\beta$-carotene degradation at different temperatures enabled the calculation of the reaction temperature sensitivity, expressed in activation energies ( $E a$ ) or the thermal resistance constant $z$. Nine values of calculated activation energies are higher than $50 \mathrm{~kJ} \cdot \mathrm{mol}^{-1}$, corresponding to $z$ values inferior to $34^{\circ} \mathrm{C}$. This can show a peculiar temperature sensitivity of $\beta$-carotene towards an elevation of temperature, which is not necessarily the case for all vitamins. For instance, Dhuique-Mayer et al. found activation energy of $35 \mathrm{~kJ} \cdot \mathrm{mol}^{-1}$ for vitamin $\mathrm{C}$ degradation against $110 \mathrm{~kJ} \cdot \mathrm{mol}^{-1}$ for $\beta$-carotene in citrus juice [33]. Heat seems to activate nearly all $\beta$-carotene degradation pathways. It has been evidenced that heat induces isomerisation of the all-trans- $\beta$-carotene to the cis forms, which can be explained by the more elevated electron mobility with temperature increase. Heat also favours oxidation. Indeed, the formation of a free radical is a reaction presenting a high activation energy (from $146 \mathrm{~kJ} \cdot \mathrm{mol}^{-1}$ to $272 \mathrm{~kJ} \cdot \mathrm{mol}^{-1}$ ) so it can be facilitated by high temperatures [55].

However, despite this tendency, activation energies $(E a)$ and thermal resistance values $(z)$ are supposed to be independent of products or process conditions. However, values of $E a$ range between (14 and 188) $\mathrm{kJ} \cdot \mathrm{mol}^{-1}$ and $z$ values from (11 to 179) ${ }^{\circ} \mathrm{C}$. They exhibit therefore a significant dispersion. Therefore, sensitivity to heat is obviously very dependent on the process and product. Indeed, the $\beta$-carotene reaction is very dependent on the presence of co-substrates (see section 3.4.1.) which may be found in very different concentrations in different food matrices. Lastly, a global measure such as colour may include other reactions. In addition, activation energies 


\section{Pénicaud et al.}

Figure 5.

Simplified $\beta$-carotene degradation scheme of carotenoids in a model cashew apple juice by Zepka et al. [51].

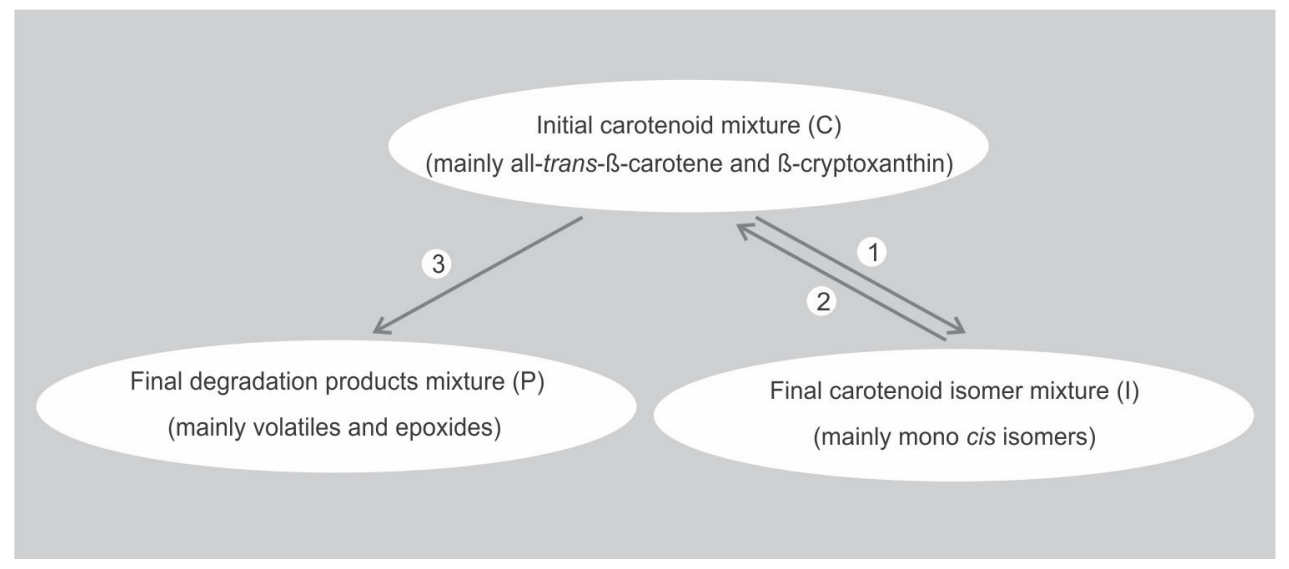

Table III.

Values of kinetic parameters obtained for the simplified $\beta$-carotene degradation scheme of carotenoids in a model cashew apple juice [51] described in figure 5.

\begin{tabular}{lccc} 
Kinetic parameter & $\begin{array}{c}\text { Reaction } 1 \\
\mathrm{C} \rightarrow \mathrm{I}\end{array}$ & $\begin{array}{c}\text { Reaction } 2 \\
\mathrm{I} \rightarrow \mathrm{C}\end{array}$ & $\begin{array}{c}\text { Reaction 3 } \\
\mathrm{C} \rightarrow \mathrm{P}\end{array}$ \\
\hline $\mathrm{K}_{60}{ }^{\circ} \mathrm{C}\left(\mathrm{s}^{-1}\right)$ & $8.3 \pm 2.8 \times 10^{-7}$ & $5.8 \pm 1.1 \times 10^{-6}$ & $15.4 \pm 1.1 \times 10^{-5}$ \\
$\mathrm{k}_{90}{ }^{\circ} \mathrm{C}\left(\mathrm{s}^{-1}\right)$ & $3.1 \pm 0.6 \times 10^{-5}$ & $6.1 \pm 1.4 \times 10^{-5}$ & $18.5 \pm 2.2 \times 10^{-4}$ \\
$\mathrm{E}_{\mathrm{a}}\left(\mathrm{kJ} \cdot \mathrm{mol}^{-1}\right)$ & $114.2 \pm 18.8$ & $78.2 \pm 10.5$ & $82.8 \pm 8.4$
\end{tabular}

found under $100{ }^{\circ} \mathrm{C}$ with a significant temperature range $\left(50{ }^{\circ} \mathrm{C}\right.$ to $\left.90{ }^{\circ} \mathrm{C}\right)[33,53]$ may be hard to compare with a process above $100{ }^{\circ} \mathrm{C}$ with a narrow temperature range $\left(100{ }^{\circ} \mathrm{C}\right.$ to $\left.125^{\circ} \mathrm{C}\right)[53]$. Therefore, activation energies found in the literature must be taken with precaution. In many cases, they are calculated empirically and are valuable to design process conditions only for a given application. In addition, they give no further insight into the degradation mechanism and, therefore, no transposition can be made for other products or processes.

Some studies followed not only $\beta$-carotene degradation but also degradation product apparition. Zepka et al. identified the reaction rates according to the reaction scheme of figure 5 at different temperatures from $60{ }^{\circ} \mathrm{C}$ to $90{ }^{\circ} \mathrm{C}$ in a cashew apple juice model [51]. From the values of kinetic constant rates they obtained on the basis of both carotenoid level and colour parameter changes (table III), it was clear that $k_{3}$ was largely superior to $k_{1}$ and $k_{2}$, indicating that the formation of degradation compounds was much faster than the isomerisation process. From these data, a rough estimation of the activation energy $E_{\mathrm{a}, \mathrm{i}}$ of each individual reaction was possible (table III), assuming a linear behaviour of the classical Arrhenius equation between both temperatures. The activation energies of the irreversible formation of degradation compounds (reaction 3) and of the cis $\rightarrow$ trans backisomerisation reaction (reaction 2) were almost the same, and are both lower than that of the direct formation of the mono-cis isomers (reaction 1). That means that reaction 1 is the less favoured one, while reactions 2 and 3 are equally favoured. However, the $\left[k_{3} / k_{2}\right] \approx 30$ indicated that the formation of degradation compounds was a highly entropic process, probably due to breakdown of the large all-trans molecules into shorter-chain derivatives. In addition, the present mechanism allowed the calculation of the overall activation energy for the thermal degradation of the main 
all-trans carotenoids in the cashew apple juice model as $\left(E_{\mathrm{a}, 1}-E_{\mathrm{a}, 2}\right)+E_{\mathrm{a}, 3}=$ $118.6 \mathrm{~kJ} \cdot \mathrm{mol}^{-1}$, a value comparable with the values detailed in table II.

Such an approach is very interesting from a mechanistic point of view, since it supplies evidence to complete theoretical calculations and studies carried out in model systems. In this study, the authors proposed a model which tends to refute the idea that $\beta$-carotene degradation would preferentially go through a first step of isomerisation. It would have been of great interest to compare their results with those obtained with a model in which the isomers would have been the intermediary products between trans-carotenoids and cleavage products. This could have been a way to discuss the two supposed reaction mechanisms. What is certain is that degradation products increase with processing time and temperature. That is the case for isomers [18, 19, 56] and also for oxidative products, although they are more reactive and harder to measure [19].

\subsection{Effect of oxygen}

The antioxidant activity of $\beta$-carotene consists either of physical quenching of singlet oxygen or scavenging reactive oxygen species. This antioxidant activity being part of the degradations that $\beta$-carotene can undergo, occurrence of oxygen in food can obviously impact the $\beta$-carotene degradation rate.

However, at first, the effect of oxygen was mostly studied from a mechanistic point of view. In the self-initiated oxidation of $\beta$-carotene with molecular oxygen, the rate of oxygen uptake was shown to depend on the oxygen partial pressure [40]. Perez-Galvez and Minguez-Mosquera also stated that oxygen was the more important limiting factor in carotene degradation in lipid systems [12]. Tsuchihashi et al. even proposed reaction pathways for the reaction of $\beta$-carotene in lipid systems [43]. Peroxyl radical was supposed to add to $\beta$-carotene to give a stable $\beta$-carotene radical which may undergo several competing reactions. It may react with another radical to give a stable product. It may react with oxygen to yield a $\beta$-carotene peroxyl radical, which may react with another radical to give stable products, attack another $\beta$-carotene molecule to induce an autoxidation of $\beta$-carotene, or attack a substrate such as lipid to generate lipid radical and induce chain oxidation. The $\beta$-carotene radical may also undergo $\beta$-scission to give an epoxide and alkoxyl radical, which may continue oxidation. The effect of oxygen is thus a major one.

In real food products, most of the studies consist of comparisons of carotenoid degradation (or retention) level when food is submitted to different oxygen levels. For instance, high oxygen concentrations have been associated with high levels of carotenoid degradation during storage in dried sweet potato flakes [57], in pasteurised mango puree [29] and in semi-preserved tomato sauces [58]. The occurrence of oxygen during processing has also been investigated: it was found that low-pressure superheated steam drying and vacuum drying led to less degradation of $\beta$-carotene in carrot than hot air drying because this last process was the most aerobic [18].

Some authors attempted to define more precisely the relationship between oxygen and carotenoid loss and thus related their degradation kinetic constant rates to the oxygen level around the sample. Dried sweet potato chips stored at $40{ }^{\circ} \mathrm{C}$ and flushed with nitrogen had a degradation rate constant of $12.4 \pm 2.4 \times 10^{-8} \mathrm{~s}^{-1}$, whilst those flushed with $2.5 \%, 10 \%$ and $21 \%$ oxygen had respective degradation rate constants of $3.51 \pm 0.61 \times 10^{-7} \mathrm{~s}^{-1}, 5.95 \pm 0.25 \times$ $10^{-7} \mathrm{~s}^{-1}$ and $9.87 \pm 0.44 \times 10^{-7} \mathrm{~s}^{-1}$ [17]. In oil of gac fruit, a Southeast Asian fruit, the rate of $\beta$-carotene degradation was found to be $5.0 \pm 0.5 \times 10^{-8} \mathrm{~s}^{-1}$ and $1.04 \pm 0.17 \times 10^{-7} \mathrm{~s}^{-1}$ at $45^{\circ} \mathrm{C}$ and $60{ }^{\circ} \mathrm{C}$, respectively, when samples were flushed with nitrogen, whereas they were $8.3 \pm 0.2 \times 10^{-8} \mathrm{~s}^{-1}$ and $1.57 \pm 0.5 \times$ $10^{-7} \mathrm{~s}^{-1}$ at $45^{\circ} \mathrm{C}$ and $60{ }^{\circ} \mathrm{C}$, respectively, in controls [59]. Decreasing the oxygen level in the atmosphere around the food unmistakably decreases the $\beta$-carotene loss rate.

Unfortunately, few data are available concerning the quantified impact of dissolved oxygen on $\beta$-carotene degradation rates. The authors who worked on this subject 


\section{Pénicaud et al.}

generally carried out their measurements in organic solvents or oils, taken as model systems for carotenoid degradation because the degradation pathways were more elucidated in lipids than in fruits or vegetables. Some authors experimentally studied and kinetically modelled the autoxidation of $\beta$-carotene in $n$-decane as a solvent under various conditions of temperature and initial dissolved oxygen content [60]. The kinetic model was based on a chain reaction mechanism composed of 7 reactions: 2 initiation reactions, 2 propagation reactions (including 1 reversible reaction) and 2 termination reactions. In another study, Takahashi et al. presented a kinetic model of $\beta$-carotene oxidation in the presence of an antioxidant $(\alpha-$ tocopherol) in $n$-decane (19 reactions including the co-oxidation of both carotenoids) under various conditions of temperature and constant oxygen level varying for each temperature between $(20$ and 40) $\mathrm{mol} \%$ [61]. The kinetic model proposed took into account the concentration of all reactants including oxygen and quantitatively described the oxidation of both $\beta$-carotene and $\alpha$-tocopherol over a wide range of temperatures, oxygen contents and initial antioxidant concentrations.

The same approaches were carried out not only in $n$-decane but also in oleic acid. The authors observed that, when oleic acid was the solvent of the reaction, internal oxygen mass transfer from the atmosphere into the oil had to be taken into account, probably because, in this case, oleic acid also consumed oxygen due to its own oxidation, and thus oxygen transfer was the limiting factor. Internal oxygen transfer was thus included in the proposed kinetic model, which was based on the reaction mechanism consisting of the oxidation of $\beta$-carotene ( 7 reactions), the oxidation of oleic acid ( 2 reactions), and the cross-reaction of $\beta$-carotene with oleic acid (1 reaction), i.e., a total of 10 reactions [62]. In a last study [63], oxidation experiments with $\beta$-carotene were also performed in oleic acid solvent but with the addition of $\alpha$-tocopherol. In this case again, internal oxygen transfer was taken into account. The kinetic model was based on a reaction mechanism involving 25 reactions and simulated well the time over which $\beta$-carotene was almost totally consumed under practical storage conditions at room temperature in air.

Such models can be very powerful tools to investigate effects of the different parameters acting on the degradation of the carotenoids and, conversely, to provide quantitative data on the process and storage conditions to carry out in order to minimise carotenoid loss. However, development of these mechanistic models involves the knowledge of the oxygen concentration in the medium. Besides, the models cited above were based and validated on experimental contents of antioxidants or oxidation products, but not on oxygen content. Thus, the influence of oxygen which is obtained from these models can be disputable. In fact, due to technical limitations, it is hard to obtain data about oxygen concentrations in oils, and even more difficult in fruits since they are solid. Furthermore, in real food, the measurement of oxygen solubility is complicated by occurrence of oxidable compounds which tend to disturb measurements. From the literature, it can only be said that oxygen solubility would decrease with an increase in temperature and dry matter in aqueous products and would be higher in oils than in aqueous products [64-67]. For instance, the oxygen content in water is $13 \mathrm{mg} \cdot \mathrm{L}^{-1}$ at $4^{\circ} \mathrm{C}, 9 \mathrm{mg} \cdot \mathrm{L}^{-1}$ at $20^{\circ} \mathrm{C}$ and decreases to $0 \mathrm{mg} \cdot \mathrm{L}^{-1}$ at $100^{\circ} \mathrm{C}$, whereas, in oils, it is around $30 \mathrm{mg} \cdot \mathrm{L}^{-1}$ whatever the temperature in the range of $20^{\circ} \mathrm{C}$ to $50^{\circ} \mathrm{C}$. In the case of solid foods, oxygen transfer is limiting because of the low oxygen diffusion coefficients from the atmosphere into the food [68]. However, the knowledge of the diffusion coefficient of the oxygen in the food is a parameter very hard to achieve experimentally. Despite many improvements during the last century, oxygen quantification remains nowadays the main bottleneck to enlarging knowledge on the oxygen impact on food products [2, 69]. Some recent oxygen probes (optical fibre of about $100 \mu \mathrm{m}$ in diameter, for example), based on luminescence quenching by the oxygen, should help researchers to investigate this area since these sensors present the advantages of consuming no oxygen and 
allowing high spatial resolution in all materials [68-70].

\subsection{Effect of food matrix}

Because of the diversity of fruits and vegetables and the complexity of their composition, the effect of the food matrix on $\beta$-carotene degradation is very difficult to understand. Two major factors can be evidenced: the composition in itself, and the structure of $\beta$-carotene in the food, which is dependent on the type and structure of the product: liquid, solid, emulsion, etc.

\subsubsection{Effect of food composition}

Composition is very different among the various vegetables and fruits according to the different genre, species and variety. Even in the same variety, composition variations may occur because of the climatic conditions. Moreover, sometimes, in the same fruit, composition difference may occur as a function of its different parts. Therefore, kinetic studies are very hard to conduct on real products, explaining why some authors have attempted to elucidate some kinetic parameters on model food.

- Water: It has been evidenced that the lower the water activity, the faster the $\beta$-carotene degradation. During isothermal storage at $40{ }^{\circ} \mathrm{C}$ under air of dried sweet potato chips, water activity $\left(\mathrm{a}_{\mathrm{w}}=0.13-0.76\right)$ had a significant impact on carotenoid degradation, with rate constants varying between $5.71 \times 10^{-7} \mathrm{~s}^{-1}$ and $3.95 \times 10^{-7} \mathrm{~s}^{-1}$, respectively [17]. Previous research on freeze-dried sweet potato cubes also showed higher levels of $\beta$-carotene degradation at lower water activities [71].

- Acid: The effect of acid on carotenoid degradation has been reported in a few studies. Mortensen et al. studied degradation of carotenoids with nitric acid and moderately strong acids, such as trichloroacetic and trifluoroacetic acids [72]. The intermediary reactions were mono- and di-protonated carotenoids, which exhibited a long lifetime (hours) in the experimental conditions of the study. It has also been shown that organic acids liberated during the processing of fruit juices are strong enough to promote rearrangements of 5,6-epoxide groups into 5,8-furanoid groups of carotenoids [33, 73].

- Lipid unsaturation: Liu and Chen studied $\beta$-carotene degradation in an oil model at $60{ }^{\circ} \mathrm{C}$ and $120^{\circ} \mathrm{C}$ [56]. Higher degradation rates were found in saturated fatty acids than in unsaturated fatty acids. They stated that unsaturated lipids were prone to reacting with oxygen and therefore could enter into competition with $\beta$-carotene. However, on the contrary, Goulson and Warthesen [74] and Budowski and Brondi [75] observed that carotene degradation increased as the degree of oil unsaturation increased. They considered that this higher rate was due to the faster oxidation of unsaturated lipids producing radicals likely to attack carotenes. Lastly, Perez-Galvez and MinguezMosquera evidenced that carotenoids could react with oxidative products of lipids but did not find any differences in carotene degradation in different fatty acid substrates [76]. The influence of lipid unsaturation is thus unclear.

- Antioxidants: Many biological studies report interactions of carotenoids with other antioxidants, and particularly with vitamin $\mathrm{E}$ and C. Vitamin E is a generic name gathering eight tocochromanols (four tocopherols and four tocotrienols). Tocochromanols are also lipophilic and can be encountered in oils containing $\beta$-carotene such as palm oils [77]. These molecules proved to have a better chain-breaking action than $\beta$-carotene, particularly in free-radical-induced peroxidation [11]. Besides, some works report a protective role of tocochromanols, particularly $\alpha$ - and $\gamma$-tocopherol, against $\beta$-carotene autoxidation [78]. This protective role has been shown in lipid models such as purified triacyl glycerol fraction [79] or in oleic acid $[61,63]$. Some degradation studies in oil systems even showed that carotenes and tocochromanols had synergistic effects in their protective effects. Indeed, in a membrane model, a combination of $\beta$-carotene and $\alpha$-tocopherol inhibited lipid peroxidation greater than the sum of the individual inhibitions [80]. In vitro, interactions were also demonstrated by Packer between $\beta$-carotene and ascorbic acid (vitamin $\mathrm{C}$ ) in lowdensity proteins [81]. Ascorbic acid was 


\section{Pénicaud et al.}

proven to act synergistically with $\beta$-carotene to prevent oxidation and $\beta$-carotene loss. However, as ascorbic acid is hydrosoluble, interactions with $\beta$-carotene are possible only in particular amphiphilic structures, such as cellular membranes or emulsions.

- Metals: Contrary to antioxidants, metals have an oxidant role. Polyakov et al. stated that $\beta$-carotene offers little protection against metal-induced lipid peroxidation [82]. Indeed, as unsaturated lipids, carotenoids can be oxidised by transition metal especially at low pH [83]. Metals studied in such reactions are iron [83] and copper [78].

\subsubsection{Effect of structure}

During processing, micronutrients in fruits or vegetables are firstly degraded because of the first steps of tissue breakdown during cutting, blending or crushing. Oxidative reactions occur as a result of the contact with ambient air but degradations may also occur because of the disorganisation of initial cellular structures and solubilisation in other solvents. In plants, carotenoids are located in the chromoplasts. Microscopic studies reveal that within the chromoplast, $\beta$-carotene can be either in a crystalline form or partially solubilised in lipid droplets as a function of the vegetable [29, 84]. For instance, it has been shown that, in mango, $\beta$-carotene was preferentially solubilised in lipid droplets and also that a large portion of cis- $\beta$-carotene naturally occurs [85] whereas, in carrot, it is mostly present in crystalline form and the all-trans isomer predominates [26]. Furthermore, the addition of grape oil to carrot juice before heat treatment enhanced the 13 -cis- $\beta$-carotene formation (18.8\%) as compared with the control (6\%) [26]. This fact was attributed to the partial dissolution of crystalline carotene, present in the intact carrot in lipid droplets, indicating that the solubilisation of carotenes was a prerequisite for the formation of cis-isomers. It was also noted that the reverse reaction, isomerisation of cis- to trans-isomer, occurred in partly melted solid $\beta$-carotene when $\beta$-carotene was heated at $90{ }^{\circ} \mathrm{C}$ and $140{ }^{\circ} \mathrm{C}$ [41]. Chen and Huang added that the level of isomerisation of $\beta$-carotene was dependent on the solvent and that higher levels were reached in nonpolar solvents [27].

The solvent in which carotenoids are solubilised may also have an effect on their global degradation. Indeed, in polar solvents such as water, the oxycarotenoids proved to degrade much faster than the carotenes [33]. On the contrary, in organic solution, Olatunde Farombi and Britton found initial rates of oxidation superior for $\beta$-carotene than for lutein, an oxycarotenoid [86]. They suggested that lutein, with its hydroxyl group, was more polar than $\beta$-carotene and may possibly react less in a non-polar solvent.

The protective effect of the food structure on $\beta$-carotene has been particularly investigated in tomato products during heat treatments [87]. The main results showed that $\beta$-carotene was more sensitive to isomerisation than lycopene. Indeed, the heat treatment imparted changes or deformation of the physical ultrastructure of the cell wall and organelles, and $\beta$-carotene with its two bulky $\beta$-ionone rings could hardly reorganise and bear these changes as lycopene did. Similar results were obtained during hotbreak processing of tomato juice and even of tomato paste; the amounts of trans- and cis- lycopene isomers remained almost unchanged, whereas increased levels of cis$\beta$-carotene were found [88]. These different studies evidenced that the nature of the structure where carotenoids are deposited and the physical state of the pigments are crucial for the stability of the all-trans configuration.

\section{Discussion and conclusion}

Industrial food processing is often incriminated in lowering the nutritional value of products. Therefore, there is an increasing demand to understand and prevent the degradation of nutrients during processing and storage.

The first approach consists of the establishment of reaction pathways which can lead to nutrient losses. In the case of $\beta$-carotene, it has been shown that both isomerisation and oxidation could decrease the content of this vitamin, corresponding to 
about thirty identified degradation products and at least as many reactions only in the case of autoxidation. Still, not all autoxidation reactions have been fully elucidated. That means that if enzymatic oxidation, photoxidation and eventually co-oxidation with lipid substrates or other antioxidants had been considered, hundreds of reactions could have been found. Yet, all these degradation pathways could potentially occur in a real food product.

Under these conditions, the second approach, the kinetic one, seems obvious. Among all the possible degradation pathways, which ones are the fastest and thus which ones will predominate for a given product submitted to a known process or storage conditions? Concomitantly, the development of analysis automation techniques encourages researchers to sophisticate kinetics monitoring of degradation reactions during processing. Therefore, different studies report kinetic parameters such as reaction order, rate constant and activation energies for particular degradation molecules such as cis isomers. As extensively detailed in our review, some evidence can be pointed out on the basis of kinetic analysis. For instance, it is clear that $\beta$-carotene degradation increases with processing time and temperature, and for all degradation pathways. Furthermore, Arrhenius and Bigelow models are adequate to describe the influence of the temperature on kinetic rates. It can also be said that the environmental level of oxygen significantly impacts $\beta$-carotene degradation: the more oxygen, the faster the degradation for both processing and storage. On the contrary, the lower the water activity of the food, the faster the $\beta$-carotene degradation. It has also been shown that the occurrence of antioxidants such as tocopherols (vitamin E) or ascorbic acid (vitamin C) could lower the $\beta$-carotene degradation rate, whilst metals such as iron or copper could increase it. In most of the kinetic studies, one-order kinetics is used and is generally realistic. However, the majority of studies exhibit only a global and unique degradation response such as colour loss, which hides the mechanism and dissimulates the degree of freedom in the control of reactions. These studies allow drawing general trends, among them the ones cited above, but the quantified impact of each parameter is still difficult to obtain. The drawback is that knowledge cannot be capitalised. Therefore, the data are very different from one study to another and are just empirical data valuable for one food and process application in similar conditions. To improve kinetic models, a more precise reaction monitoring should be done in order to control, anticipate and predict degradation reactions better. In particular, monitoring of apocarotenals, apocarotenones and oxygen would be helpful. However, the theoretical pathways are numerous, thus a precise monitoring of all degradation reactions seems impossible. Moreover, some reactions may be strongly correlated and it can be hard to precisely attribute a quantified product to a specific reaction. A multidisciplinary approach could help to simplify the monitoring of reactions. A literature review and thermodynamic analysis are interesting to highlight the more probabilistic pathways. The examination of degradation kinetics is also necessary in order to identify the most important reactions in terms of rate. The analytical considerations and the literature review combined with the thermodynamic and kinetic data allow the building of an observable degradation scheme which should represent the predominant pathways. This observable degradation scheme should include the main factors affecting the fate of the studied compound, such as time and temperature, for instance, and should be expressed through mathematical language, as Zepka et al. attempted to do in a rough way [51]. By improving the complexity of the reaction scheme, a modelling approach could combine mechanistic, thermodynamic and kinetic considerations, as has already been done for other chemical reactions in food; for instance, the Maillard reaction [89]. Such models are very powerful because they permit one to capitalise a lot of information. The effects of the factors involved (duration time and temperature, for example) can be quantified and the behaviour of the system can be predicted, which is very interesting from a knowledge improvement point of view. Conversely, these models allow the establishment of the operating conditions necessary to obey a 


\section{Pénicaud et al.}

quality criterion, such as a retention level in micronutrients, for instance, but not only with one degree of freedom since the effect of several parameters can be introduced into the model. Moreover, whilst empirical data are generally based on time-consuming experiments and have to be determined for each new problem, such models are fully transferable from one case to another, and could thus be very useful for the food industry.

\section{References}

[1] Lewinsohn E., Sitrit Y., Bar E., Azulay Y., Ibdah M., Meir A., Yosef E., Zamir D., Tadmor Y., Not just colors-carotenoid degradation as a link between pigmentation and aroma in tomato and watermelon fruit, Trends Food Sci. Technol. 16 (2005) 407-415.

[2] Pallett K.E., Young A.J., Carotenoids, in: Alscher, R.G., Hess, J.L. (Eds.), Antioxidants in higher plants, CRC Press, Boca Raton, FL, U.S.A., 1993, 91-110.

[3] Gaziano J.M., Johnson E.J., Russell R.M., Manson J.E., Stampfer M.J., Ridker P.M., Frei B., Hennekens C.H., Krinsky N.I., Discrimination in absorption or transport of $\beta$ carotene isomers after oral supplementation with either all-trans- or 9-cis- $\beta$-carotene, Am. J. Clin. Nutr. 61 (2009) 1248-1252.

[4] Rodriguez-Amaya D.B., A guide to carotenoid analysis in foods, OMNI Research, Washington, D.C., U.S.A., 2001, 71 p.

[5] Dutta D., Dutta A., Raychaudhuri U., Chakraborty R., Rheological characteristics and thermal degradation kinetics of $\beta$-carotene in pumpkin puree, J. Food Eng. 76 (2006) 538546.

[6] Mortensen A., Analysis of a complex mixture of carotenes from oil palm (Elaeis guineensis) fruit extract, Food Res. Int. 38 (2005) 847853.

[7] Rios J.J., Fernández-García E., MínguezMosquera M.I., Pérez-Gálvez A., Description of volatile compounds generated by the degradation of carotenoids in paprika, tomato and marigold oleoresins, Food Chem. 106 (2008) 1145-1153.

[8] Britton G., Liaaen-Jensen S., Pfander H., Carotenoids, Vol. 1B: Spectroscopy, Birkhäuser-Verlag, Basel, Switzerland, 1995.

[9] Mohamed N., Hashim R., Rahman N.A., Zain S.M., An insight to the cleavage of $\beta$-caro- tene to vitamin A: a molecular mechanics study, J. Mol. Struct. 538 (2001) 245-252.

[10] Borel P., Drai J., Faure H., Fayol V., Galabert C., Laromiguiere M., Le Moel G., Recent knowledge about intestinal absorption and cleavage of carotenoids, Ann. Biol. Clin. 63 (2005) 165-177.

[11] Laguerre M., Lecomte J., Villeneuve P., EvaIuation of the ability of antioxidants to counteract lipid oxidation: Existing methods, new trends and challenges, Progr. Lipid Res. 46 (2007) 244-282.

[12] Perez-Galvez A., Minguez-Mosquera M.I., Structure-reactivity relationship in the oxidation of carotenoid pigments of the pepper (Capsicum annuum L.), J. Agric. Food Chem. 49 (2001) 4864-4869.

[13] Ozhogina O.A., Kasaikina O.T., $\beta$-Carotene as an interceptor of free radicals, Free Radic. Biol. Med. 19 (1995) 575-581.

[14] Warner K., Frankel E.N., Effects of $\beta$-carotene on light stability of soybean oil, J. Am. Oil Chem. Soc. 64 (1987) 213-218.

[15] Bureau S., Renard C.M.G.C., Reich M., Ginies C., Audergon J.-M., Change in anthocyanin concentrations in red apricot fruits during ripening, LWT - Food Sci. Technol. 42 (2009) 372-377.

[16] Liu L.H., Zabaras D., Bennett L.E., Aguas P., Woonton B.W., Effects of UV-C, red light and sun light on the carotenoid content and physical qualities of tomatoes during post-harvest storage, Food Chem. 115 (2009) 495500 .

[17] Bechoff A., Dhuique-Mayer C., Dornier M., Tomlins K.I., Boulanger R., Dufour D., Westby A., Relationship between the kinetics of $\beta$-carotene degradation and formation of norisoprenoids in the storage of dried sweet potato chips, Food Chem. 121 (2010) 348-357.

[18] Hiranvarachat B., Suvarnakuta P., Devahastin S., Isomerisation kinetics and antioxidant activities of $\beta$-carotene in carrots undergoing different drying techniques and conditions, Food Chem. 107 (2008) 1538-1546.

[19] Rodriguez E.B., Rodriguez-Amaya D.B., Formation of apocarotenals and epoxycarotenoids from $\beta$-carotene by chemical reactions and by autoxidation in model systems and processed foods, Food Chem. 101 (2007) 563-572.

[20] Thurnham D.I., Bioequivalence of $\beta$-carotene and retinol, J. Sci. Food Agric. 87 (2007) 13-19. 
[21] Zhang P., Omaye S.T., $\beta$-Carotene: interactions with $\alpha$-tocopherol and ascorbic acid in microsomal lipid peroxidation, J. Nutr. Biochem. 12 (2001) 38-45.

[22] Mordi R.C., Mechanism of $\beta$-carotene degradation, Biochem. J. 292 (1993) 310-312.

[23] Stahl W., Sies H., Carotenoids and protection against solar UV radiation, Skin Pharmacol. Appl. Physiol. 15 (2002) 291-296.

[24] Sander L.C., Sharpless K.E., Craft N.E., Wise S.A., Development of engineered stationary phases for the separation of carotenoid isomers, Anal. Chem. (1994) 1667-1674.

[25] Britton G., Liaanen-Jensen S., Pfander H., Carotenoids handbook, Birkhaüser Verlag Basel, Switz., 2004.

[26] Marx M., Stuparic M., Schieber A., Carle R., Effects of thermal processing on trans-cisisomerization of $\beta$-carotene in carrot juices and carotene-containing preparations, Food Chem. 83 (2003) 609-617.

[27] Chen B.H., Huang J.H., Degradation and isomerization of chlorophyll $a$ and $\beta$-carotene as affected by various heating and illumination treatments, Food Chem. 62 (1998) 299-307.

[28] Henry L.K., Catignani G., Schwartz S., Oxidative degradation kinetics of lycopene, lutein, and 9-cis and all-trans- $\beta$-carotene, J. Am. Oil Chem. Soc. 75 (1998) 823-829.

[29] Vásquez-Caicedo A.L., Schilling S., Carle R., Neidhart S., Effects of thermal processing and fruit matrix on $\beta$-carotene stability and enzyme inactivation during transformation of mangoes into puree and nectar, Food Chem. 102 (2007) 1172-1186.

[30] Schieber A., Marx M., Carle R., Simultaneous determination of carotenes and tocopherols in ATBC drinks by high-performance liquid chromatography, Food Chem. 76 (2002) 357-362.

[31] Kidmose U., Yang R.Y., Thilsted S.H., Christensen L.P., Brandt K., Content of carotenoids in commonly consumed Asian vegetables and stability and extractability during frying, J. Food Compos. Anal. 19 (2006) 562-571.

[32] Koca N., Burdurlu H.S., Karadeniz F., Kinetics of colour changes in dehydrated carrots, J. Food Eng. 78 (2007) 449-455.

[33] Dhuique-Mayer C., Tbatou M., Carail M., Caris-Veyrat C., Dornier M., Amiot M.J., Thermal degradation of antioxidant micronutrients in citrus juice: kinetics and newly formed compounds, J. Agric. Food Chem. 55 (2007) 4209-4216.
[34] Caris-Veyrat C., Amiot M.J., Ramasseul R., Marchon J.C., Mild oxidative cleavage of $\beta$-carotene by dioxygen induced by a ruthenium porphyrin catalyst: characterization of products and of some possible intermediates, New J. Chem. 25 (2001) 203-206.

[35] Nonier M.F., De Gaulejac N.V., Vivas N., Vitry C., Characterization of carotenoids and their degradation products in oak wood. Incidence on the flavour of wood, C. R. Chim. 7 (2004) 689-698.

[36] Sommerburg O., Langhans C.D., Arnhold J., Leichsenring M., Salerno C., Crifo C., Hoffmann G.F., Debatin K.M., Siems W.G., $\beta$-Carotene cleavage products after oxidation mediated by hypochlorous acid - A model for neutrophil-derived degradation, Free Radic. Biol. Med. 35 (2003) 1480-1490.

[37] Bosser A., Belin J.M., Synthesis of $\beta$-Ionone in an aldehyde/xanthine oxidase/ $\beta$-carotene system involving free-radical formation, Biotechnol. Progress. 10 (1994) 129-133.

[38] Bosser A., Paplorey E., Belin J.M., A simple way to (+/-)-dihydroactinidiolide from $\beta$-ionone related to the enzymatic cooxidation of $\beta$-carotene in aqueous-solution, Biotechnol. Prog. 11 (1995) 689-692.

[39] Wache Y., Bosser-DeRatuld A., Lhuguenot J.C., Belin J.M., Effect of cis/trans isomerism of $\beta$-carotene on the ratios of volatile compounds produced during oxidative degradation, J. Agric. Food Chem. 51 (2003) 19841987.

[40] Mordi R.C., Walton J.C., Burton G.W., Hughes L., Keith I.U., David L.A., Douglas M.J., Oxidative degradation of $\beta$-carotene and $\beta$-apo-8'-carotenal, Tetrahedron 49 (1993) 911-928.

[41] Qiu D., Chen Z.R., Li H.R., Effect of heating on solid $\beta$-carotene, Food Chem. 112 (2009) 344-349.

[42] Kennedy T.A., Liebler D.C., Peroxyl radical scavenging by $\beta$-carotene in lipid bilayers Effect of oxygen partial-pressure, J. Biol. Chem. 267 (1992) 4658-4663.

[43] Tsuchihashi H., Kigoshi M., Iwatsuki M., Niki E., Action of $\beta$-carotene as an antioxidant against lipid peroxidation, Arch. Biochem. Biophys. 323 (1995) 137-147.

[44] Furr H.C., Analysis of retinoids and carotenoids: Problems resolved and unsolved, J. Nutr. 134 (2004) 281S-285S.

[45] Wu X., Sun C.J., Yang L.H., Zeng G., Liu Z.Y., Li Y.M., $\beta$-Carotene content in sweet potato varieties from China and the effect of preparation on $\beta$-carotene retention in the Yanshu 
No. 5, Innov. Food Sci. Emerg. Technol. 9 (2008) 581-586.

[46] Shin J.H., Chung H.L., Seo J.K., Sim J.H., Huh C.S., Kil S.K., Baek Y.J., Degradation kinetics of Capsanthin in paprika (Capsanthin annuum L.) as affected by heating, J. Food Sci. 66 (2001) 15-18.

[47] Achir N., Randrianatoandro V.A., Bohuon P., Laffargue A., Avallone S., Kinetic study of $\beta$ carotene and lutein degradation in oils during heat treatment, Eur. J. Lipid Sci. Technol. 112 (2010) 349-361.

[48] Avallone S., Rojas-Gonzalez J.A., Trystram G., Bohuon P., Thermal sensitivity of some plantain micronutrients during deep-fat frying, J. Food sci. 74 (2009) C339-C347.

[49] Fratianni A., Cinquanta L., Panfili G., Degradation of carotenoids in orange juice during microwave heating, LWT - Food Sci. Technol. 43 (2010) 867-871.

[50] Baldermann S., Naim M., Fleischmann P., Enzymatic carotenoid degradation and aroma formation in nectarines (Prunus persica), Food Res. Int. 38 (2005) 833-836.

[51] Zepka L.Q., Borsarelli C.D., Azevedo M.A., da Silva P., Mercadante A.Z., Thermal degradation kinetics of carotenoids in a cashew apple juice model and its impact on the system color, J. Agric. Food Chem. 57 (2009) 7841-7845.

[52] Melendez-Martinez A.J., Vicario I.M., Heredia F.J., Application of tristimulus colorimetry to estimate the carotenoids content in ultrafrozen orange juices, J. Agric. Food Chem. 51 (2003) 7266-7270.

[53] Vikram V.B., Ramesh M.N., Prapulla S.G., Thermal degradation kinetics of nutrients in orange juice heated by electromagnetic and conventional methods, J. Food Eng. 69 (2005) 31-40.

[54] Limbo S., Torri L., Piergiovanni L., Lightinduced changes in an aqueous $\beta$-carotene system stored under halogen and fluorescent lamps, affected by two oxygen partial pressures, J. Agric. Food Chem. 55 (2007) 5238-5245.

[55] Cheftel J.C., Introduction à la biochimie et à la technologie des aliments, Tech. \& Doc. Lavoisier, Paris, France, 1992.

[56] Liu M.H., Chen B.H., Relationship between chlorophyll $a$ and $\beta$-carotene in a lipidcontaining model system during heating, Food Chem. 61 (1998) 41-47.

[57] Emenhiser C., Watkins R.H., Simunovic N., Solomons N., Bulux J., Barrows J., Schwartz S.J., Packaging preservation of $\beta$-carotene in sweet potato flakes using flexible film and an oxygen absorber, J. Food Qual. 22 (1999) 63-73.

[58] Baiano A., Tamagnone P., Marchitelli V., del Nobile M.A., Quality decay kinetics of semipreserved sauce as affected by packaging, J. Food Sci. 70 (2005) E92-E97.

[59] Nhung D.T.T., Bung P.N., Ha N.T., Phong T.K., Changes in lycopene and $\beta$-carotene contents in aril and oil of gac fruit during storage, Food Chem. 121 (2010) 326-331.

[60] Takahashi A., Shibasaki-Kitakawa N., Yonemoto T., Kinetic model for autoxidation of $\beta$-carotene in organic solutions, J. Am. Oil Chem. Soc. 76 (1999) 897-903.

[61] Takahashi A., Shibasaki-Kitakawa N., Toshikuni Y., A rigorous kinetic model for $\beta$-carotene oxidation in the presence of an antioxidant, $\alpha$-tocopherol, J. Am. Oil Chem. Soc. 80 (2003) 1241-1247.

[62] Takahashi A., Suzuki J.-I., Shibasaki-Kitakawa N., Toshikuni Y., A kinetic model for cooxidation of $\beta$-carotene with oleic acid, J. Am. Oil Chem. Soc. 78 (2001) 1203-1207.

[63] Shibasaki-Kitakawa N., Hideto K., Takahashi A., Toshikuni Y., Oxidation kinetics of $\beta$-carotene in olein acid solvent with addition of an antioxidant, $\alpha$-tocopherol, J. Am. Oil Chem. Soc. 81 (2004) 389-394.

[64] Aho L., Wahlroos O., A comparison between determinations of the solubility of oxygen in oils by exponential dilution and chemical methods, J. Am. Oil Chem. Soc. 44 (1967) 65-66.

[65] Benson B.B., Krause D.J., The concentration and isotopic fractionation of oxygen dissolved in freshwater and seawater in equilibrium with the atmosphere, Limnol. Oceanogr. 29 (1984) 620-632.

[66] Battino R., Evans F.D., Danforth W.F., Solubilities of seven gases in olive oil with reference to theories of transport through cell membrane, J. Am. Oil Chem. Soc. 45 (1968) 830-833.

[67] Ke P.J., Ackman R.G., Bunsen coefficient for oxygen in marine oils at various temperatures determined by an exponential dilution method with a polarographic oxygen electrode, J. Am. Oil Chem. Soc. 50 (1973) 429435.

[68] Pénicaud C., Guilbert S., Peyron S., Gontard N., Guillard V., Oxygen transfer in foods using oxygen luminescence sensors: Influence of oxygen partial pressure and food nature and composition, Food Chem. 123 (2010) 1275-1281. 
[69] Pénicaud C., Peyron S., Gontard N., Guillard, V., Oxygen quantification methods and application to the determination of oxygen diffusion and solubility coefficients in food, Food Rev. Int. (2011), doi:10.1080/ 87559129.2011.595021.

[70] Holst G., Glud R.N., Kühl M., Klimant I., A microoptode array for fine-scale measurement of oxygen distribution, Sens. Actuators B 38-39 (1997) 122-129.

[71] Haralampu S.G., Karel M., Kinetic-models for moisture dependence of ascorbic-acid and $\beta$-carotene degradation in dehydrated sweet-potato, J. Food Sci. 48 (1983) 18721873.

[72] Mortensen A., Skibsted L.H., Kinetics and mechanism of the primary steps of degradation of carotenoids by acid in homogeneous solution, J. Agric. Food Chem. 48 (2000) 279-286.

[73] Assuncao R.B., Mercadante A.Z., Carotenoids and ascorbic acid composition from commercial products of cashew apple (Anacardium occidentale L.), J. Food Compos. Anal. 16 (2003) 647-657.

[74] Goulson M.J., Warthesen J.J., Stability and antioxidant activity of $\beta$-carotene in conventional and high oleic canola oil, J. Food Sci. 64 (1999) 996-999.

[75] Budowski P., Brondi A., Autoxidation of carotene and vitamin $A$ influence of fat and antioxidants, Arch. Biochem. Biophys. 89 (1960) 66-73.

[76] Pérez-Gálvez A., Mínguez-Mosquera M.I., Degradation, under non-oxygen-mediated autooxidation, of carotenoid profile present in paprika oleoresins with lipid substrates of different fatty acid composition, J. Agric. Food Chem. 52 (2004) 632-637.

[77] Sambanthamurthi R., Sundram K., Tan Y.-A., Chemistry and biochemistry of palm oil, Prog. Lipid Res. 39 (2000) 507-558.

[78] Zhang P., Omaye S.T., $\beta$-Carotene and protein oxidation: effects of ascorbic acid and $\alpha$ tocopherol, Toxicology 146 (2000) 37-47.

[79] Haila K.M., Lievonen S.M., Heinonen M.I., Effects of lutein, lycopene, annatto, and $\gamma$ tocopherol on autoxidation of triglyceride, $\mathrm{J}$. Agric. Food Chem. 44 (1996) 2096-2100.

[80] Palozza P., Calviello G., Bartoli G.M., Prooxidant activity of $\beta$-carotene under $100 \%$ oxygen pressure in rat liver microsomes, Free Radic. Biol. Med. 19 (1995) 887-892.

[81] Packer L., Antioxidant action of carotenoids in vitro and in vivo and protection against oxidation of human low-density lipo-proteins, Ann. N. Y. Acad. Sci. 691 (1993) 48-60.

[82] Polyakov N.E., Leshina T.V., Konovalova T.A., Kispert L.D., Carotenoids as scavengers of free radicals in a fenton reaction: antioxidants or pro-oxidants? Free Radic. Biol. Med. 31 (2001) 398-404.

[83] Boon C.S., McClements D.J., Weiss J., Decker E.A., Role of iron and hydroperoxides in the degradation of lycopene in oil-in-water emulsions, J. Agric. Food Chem. 57 (2009) 2993-2998.

[84] Simpson D.J., Baqar M.R., Lee T.H., Fine structure of the chromoplasts of fruit of Solanum aviculare Forth. var. Brisbanense, Aust. J. Bot. 26 (1978) 783-792.

[85] Vasquez-Caceido A.L., Heller A., Neidhart S., Carle R., Chromoplast morphology and $\beta$-carotene accumulation during postharvest ripening of mango cv. 'Tommy Atkins', J. Agric. Food Chem. 54 (2006) 5769-5776.

[86] Olatunde Farombi E., Britton G., Antioxidant activity of palm oil carotenes in organic solution: effects of structure and chemical reactivity, Food Chem. 64 (1999) 315-321.

[87] Nguyen M., Francis D., Schwartz S., Thermal isomerisation susceptibility of carotenoids in different tomato varieties, J. Sci. Food Agric. 81 (2001) 910-917.

[88] Abushita A.A., Daood H.G., Biacs P.A., Change in carotenoids and antioxidant vitamins in tomato as a function of varietal and technological factors, J. Agric. Food Chem. 48 (2000) 2075-2081.

[89] Martins S., Van Boekel M., A kinetic model for the glucose/glycine Maillard reaction pathways, Food Chem. 90 (2005) 257-269.

[90] Kim Y.-N., Giraud D.W., Driskell J.A., Tocopherol and carotenoid contents of selected Korean fruits and vegetables, J. Food Compos. Anal. 20 (2007) 458-465.

[91] Kandlakunta B., Rajendran A., Thingnganing L., Carotene content of some common (cereals, pulses, vegetables, spices and condiments) and unconventional sources of plant origin, Food Chem. 106 (2008) 85-89.

[92] Bhaskarachary K., Rao D.S.S., Deosthale Y.G., Reddy V., Carotene content of some common and less familiar foods of plant origin, Food Chem. 54 (1995) 189-193.

[93] Bora P.S., Rocha R.V.M., Narain N., MoreiraMonteiro A.C., Moreira R.A., Characterization of principal nutritional components of Brazilian oil palm (Eliaes guineensis) fruits, Bioresour. Technol. 87 (2003) 1-5. 
[94] Ngoh Newilah G., Dhuique-Mayer C., RojasGonzalez J.A., Tomekpe K., Fokou E., Etoa F.X., Carotenoid contents during ripening of banana hybrids and cultivar grown in Cameroon, Fruits 64 (2009) 197-205.

[95] Dhuique-Mayer C., Caris-Veyrat C., Ollitrault P., Curk F., Amiot M.J., Varietal and interspecific influence on micronutrient contents in citrus from the Mediterranean area, J. Agric. Food Chem. 53 (2005) 2140-2145.

[96] Giuffrida D., Dugo P., Salvo A., Saitta M., Dugo G., Free carotenoid and carotenoid ester composition in native orange juices of different varieties, Fruits 65 (2010) 277-284.
[97] Goula A.M., Adamopoulos K.G., Kinetic models of $\beta$-carotene degradation during air drying of carrots, Dry. Technol. 28 (2010) 752-761.

[98] Holdsworth S.D., Thermal processing of packaged foods, Blackie Acad. \& Prof., Lond., U.K., 1997.

[99] Ahmed J., Shivhare U.S., Sandhu K.S., Thermal degradation kinetics of carotenoids and visual color of papaya puree, J. Food Sci. 67 (2002) 2692-2695.

[100]Henry L.K., Catignani G.L., Schwartz S.J., Oxidative degradation kinetics of lycopene, lutein, and 9-cis and all-trans $\beta$-carotene, J. Am. Oil Chem. Soc. 75 (1998) 823-829.

\section{La degradación del $\beta$-caroteno en el curso de la transformación o del almacenamiento de las frutas y verduras: mecanismos reactivos y aspectos cinéticos.}

Resumen - Introducción. La significativa disminución de la calidad de las frutas y verduras en el curso de su transformación preocupa mucho a la industria alimentaria. Los micronutrientes están particularmente afectados y, entre ellos, el $\beta$-caroteno que presenta interesantes propiedades sensoriales, nutricionales y biológicas. La literatura que trata la degradación del $\beta$-caroteno es muy densa, pero la naturaleza de las conclusiones difiere, en función de que el acercamiento del problema sea biológico, químico o tecnológico. Nuestro artículo propone una síntesis de puntos de vista complementarios en el estudio del $\beta$-caroteno durante la transformación y el almacenamiento de los alimentos. Reacciones de degradación. Los principales compuestos de degradación del $\beta$-caroteno identificados son los isómeros, los epóxidos, los apocarotenales y los productos de clivaje de cadena corta, entre los cuales figuran los compuestos de aromas. De la información sacada de la literatura se puede deducir un esquema reactivo detallado de las reacciones de isomerización y de auto-oxidación del $\beta$-caroteno. Las principales vías están bien documentadas, pero el esquema reactivo global permanece incompleto. Además, la mayoría de los estudios del mecanismo se llevan a cabo según un sistema modelo, por lo que dicha información no puede representar bien el comportamiento del $\beta$-caroteno en los alimentos reales. Cinéticas durante los procesos y el almacenamiento. La determinación de las cinéticas de degradación permite identificar las reacciones más rápidas, es decir, generalmente, las que tienen los impactos fuertes, así como cuantificar el efecto de los factores que pueden disminuir el contenido de $\beta$-caroteno. La temperatura, la presencia de oxígeno, la composición y la estructura afectan significativamente la velocidad de pérdida de $\beta$-caroteno. Sin embargo, las metodologías empleadas para obtener los parámetros cinéticos son muy importantes y, finalmente, la mayoría de los resultados encontrados en la literatura son específicos de un estudio y difícilmente generalizables. Discusión y conclusión. Los enfoques de mecanismos y de cinéticas proporcionan, individualmente, datos informativos interesantes para mejorar la comprensión y el seguimiento del $\beta$-caroteno. La combinación del conjunto de esta información, junto a otras consideraciones termodinámicas y analíticas, permite construir esquemas reactivos observables que pueden posteriormente ser transcritos en modelos matemáticos. Mediante este acercamiento multidisciplinario, que hoy apenas se emplea, podrían capitalizarse los conocimientos y podrían desarrollarse herramientas para mejorar la retención del $\beta$-caroteno durante las transformaciones alimentarias y el almacenamiento.

Francia / frutas / hortalizas / almacenamiento / procesamiento / carotinoides / isomerización / oxidación / degradación / reacciones químicas 